\title{
Dietary aquaculture by-product hydrolysates: impact on the transcriptomic response of the intestinal mucosa of European seabass (Dicentrarchus labrax) fed low fish meal diets
}

\author{
Alexandre Leduc ${ }^{1,4}$, Céline Zatylny-Gaudin ${ }^{1}$, Marie Robert ${ }^{1}$, Erwan Corre ${ }^{2}$, Gildas Le Corguille², Hélène Castel ${ }^{3}$, \\ Antoine Lefevre-Scelles ${ }^{3}$, Vincent Fournier ${ }^{4}$, Enric Gisbert ${ }^{5}$, Karl B. Andree ${ }^{5}$ and Joël Henry ${ }^{* *}$
}

\begin{abstract}
Background: Aquaculture production is expected to double by 2030, and demands for aquafeeds and raw materials are expected to increase accordingly. Sustainable growth of aquaculture will require the development of highly nutritive and functional raw materials to efficiently replace fish meal. Enzymatic hydrolysis of marine and aquaculture raw materials could bring new functionalities to finished products. The aim of this study was to determine the zootechnical and transcriptomic performances of protein hydrolysates of different origins (tilapia, shrimp, and a combination of the two) in European seabass (Dicentrarchux labrax) fed a low fish meal diet (5\%), for 65 days.

Results: Results were compared to a positive control fed with 20\% of fish meal. Growth performances, anterior intestine histological organization and transcriptomic responses were monitored and analyzed. Dietary inclusion of protein hydrolysates in the low fish meal diet restored similar growth performances to those of the positive control. Inclusion of dietary shrimp hydrolysate resulted in larger villi and more goblet cells, even better than the positive control. Transcriptomic analysis of the anterior intestine showed that dietary hydrolysate inclusion restored a pattern of intestinal gene expression very close to the pattern of the positive control. However, as compared to the low fish meal diet and depending on their origin, the different hydrolysates did not modulate metabolic pathways in the same way. Dietary shrimp hydrolysate inclusion modulated more metabolic pathways related to immunity, while nutritional metabolism was more impacted by dietary tilapia hydrolysate. Interestingly, the combination of the two hydrolysates enhanced the benefits of hydrolysate inclusion in diets: more genes and metabolic pathways were regulated by the combined hydrolysates than by each hydrolysate tested independently.
\end{abstract}

Conclusions: Protein hydrolysates manufactured from aquaculture by-products are promising candidates to help replace fish meal in aquaculture feeds without disrupting animal metabolism and performances.

Keywords: Hydrolysate, Fishmeal replacement, By-products, Aquaculture, Aquafeed, European seabass, Illumina RNA-sequencing, Intestinal organization, Metabolic pathways

\footnotetext{
* Correspondence: joel.henry@unicaen.fr

${ }^{1}$ Normandie University, UNICAEN, Sorbonne Universités, MNHN, UPMC Univ

Paris 06, UA, CNRS, IRD, Biologie des Organismes et Ecosystèmes Aquatiques

(BOREA), Université de Caen Normandie, Caen 14032, France

Full list of author information is available at the end of the article
}

(c) The Author(s). 2018 Open Access This article is distributed under the terms of the Creative Commons Attribution 4.0 International License (http://creativecommons.org/licenses/by/4.0/), which permits unrestricted use, distribution, and reproduction in any medium, provided you give appropriate credit to the original author(s) and the source, provide a link to the Creative Commons license, and indicate if changes were made. The Creative Commons Public Domain Dedication waiver (http://creativecommons.org/publicdomain/zero/1.0/) applies to the data made available in this article, unless otherwise stated. 


\section{Background}

Fish captures have been stabilizing since the 1980's, and in most parts of the world seafood production is now supplied by the aquaculture industry [1]. Aquaculture production is expected to double by 2030 to meet customer demand, so demands for aquafeeds and raw materials will increase accordingly [2]. Originally, fish meals (FM) manufactured from wild fish were primarily used for growing carnivorous fish species. This kind of raw material is an excellent source of highly digestible protein and fat, is well balanced in essential amino acids, and has good palatability properties [3]. However, FM availability from wild fish is limited, its price is volatile, and its inclusion at high levels in aquafeeds is not sustainable; according to Duarte et al., FM and fish oil will be depleted by 2040 [4]. Consequently, sustainable growth of aquaculture will require the development of highly nutritive and functional raw materials to replace FM efficiently. Many studies have been conducted on carnivorous species to evaluate the performance of plant-based meal (PBM) diets to efficiently replace dietary FM; many of them were remarkably efficient, with partial or total substitution of FM by PBM [5-8]. However, replacing FM by high levels of PBM may also reduce feed palatability and fish growth $[9,10]$. Imbalanced amino acid composition of PBM leads to nutritional deficiency, and feed formulae incorporating high levels of such raw materials have to be supplemented in essential free amino acids [11]. It is also now well-documented that plants contain endogenous anti-nutritive compounds and complex carbohydrates that could affect nutrient digestibility and thereby negatively impact nutritional performances [12, 13]. Moreover, high dietary inclusion of PBM in feeds for carnivorous species leads to enteritis [14, 15], as well as depressed immunity $[16,17]$. Trials had been conducted about FM replacement by PBM on European seabass and it had been shown in different trials that it was possible to replace up to $50 \%$ of dietary FM by plant based meal without modifying fish growth performances (for review Kousoulaki et al., 2015) [18].

The large availability of marine and aquaculture by-products could allow for partial replacement of wild fish-derived FM $[19,20]$. By-products from the processing of fishery and aquaculture animals are more and more considered as a potential source of raw materials for sustainable FM production [21-23]. However, the quality of the processes applied to raw materials is critical to enhance their nutritional value. In this sense, enzymatic hydrolysis could improve the palatability, nutritional quality and functional properties of the finished product [24-26]. Enzymatic hydrolysis of fish proteins results in the formation of a mixture of free amino acids, di-, tri- and oligo-peptides, and enhances the occurrence of polar groups and the solubility of hydrolysate compounds [27]. Because low-molecular-weight nitrogenous compounds are important for the feeding behavior [28], nutrition [29-31] and health [32, 33] of aquaculture species, protein hydrolysates could be good candidates for high FM substitution in aquafeeds. However, protein hydrolysate performances could be highly dependent on the methods used for their production: their nutritional and functional properties are closely related to their characteristics and composition, including the abundance and diversity of different oligo-peptides [34, 35].

Dietary shrimp hydrolysates stimulate growth performances in fish, and also possess antimicrobial properties against aquaculture pathogens [36-39]. Similarly, tilapia hydrolysates as well as other fish hydrolysates have been evaluated; functional properties have been evidenced, such as antioxidant [24] and antimicrobial [40] activities. In particular, Khosravi et al. showed that high levels of FM could be replaced by low levels of protein hydrolysate combined with PBM in aquafeeds [38]. In addition, health benefits (i.e. immunity and gut cellular organization) of dietary protein hydrolysates have been reported in different fish species under challenging conditions [32, 38, 39, 41].

The European seabass (Dicentrarchus labrax, Linnaeus, 1758) is a marine fish widely reared in the Mediterranean sea, with more than 156,449 tons produced in 2014 [1]. It is a strictly carnivorous species [42] that requires a high level of animal proteins in its diet. For instance, the natural diet of wild European seabass contains ca. $43-50 \%$ of animal proteins [43], whereas aquafeeds for this species generally contain at least $20 \%$ of FM to support good fish performances [44]. Thus, replacing FM in European seabass aquafeed is still a major objective for the aquaculture industry. Although the complete replacement of FM by PBM has been reported as possible for European seabass, feed formulation required palatability enhancers to improve feed intake, as well as amino acid supplementation to avoid nutritional deficiency linked to PBM [6]. Trials recently conducted in European seabass showed that 5\% inclusion of shrimp- and tilapia-based protein hydrolysates associated with a combination of PBM successfully replaced 15\% FM without affecting growth or health performances [45].

The intestine is involved not only in digestion and feed absorption, but also in water and electrolyte balance, nutrient sensing, and immunity. This functional diversity is gradually being elucidated in fish, as different histological and molecular approaches provide new items of knowledge regarding the many vital functions conducted along the gastrointestinal tract $[46,47]$. In this view, the numbers of transcriptomic studies in aquaculture have increased, mostly in the field of nutrition and immunity. 
Many of them have focused on understanding how specific diets and functional ingredients could modulate metabolic pathways and regulate specific tissue expression [48-50]. But the effect of dietary protein hydrolysates on the regulation of fish metabolism has never been investigated so far.

We evaluated the effects of protein hydrolysates of different origins on European seabass fed a low FM diet. In addition to growth performances, we also studied the cellular organization and gene responses of the intestinal mucosa to investigate the effects of dietary protein hydrolysates on fish metabolism.

\section{Methods}

\section{Diets}

Five diets were formulated as follows: 2 diets containing FM at 5 and $20 \%$ of dry matter (diets FM5 and FM20) and 3 more diets containing 3 protein hydrolysates, shrimp-based hydrolysate $(\mathrm{SH})$, tilapia hydrolysate $(\mathrm{TH})$ and a 50/50 mixture of the two (MH), included at $5 \%$ of dry matter in the FM5 diet (Additional file 1). Both protein hydrolysates were provided by Aquativ (Diana Aqua, Symrise group, Elven, France). They were produced from the cephalothorax of white shrimp (Litopenaeus vannamei) and from Nile tilapia (Oreochromis niloticus) carcasses obtained from commercial food processing plants. These two protein hydrolysates have very different peptide profiles $[37,40]$. All the diets were balanced for deficient amino acids according to the requirements determined for European seabass [51]. Diets manufactured by BIOMAR (Tech Centre, Brande, Denmark) were extruded with 2 different pellet diameters -1.5 and $2.5 \mathrm{~mm}$ - for them to be adapted to the size of the fish during the trial. Diets were isoproteic $(42.7 \pm 1.1 \%$ of crude protein), isolipidic (19.3 $\pm 0.5 \%$ of crude fat) and isoenergetic $(5.2 \pm 0.1 \mathrm{~kJ} / \mathrm{kg})$.

\section{Animals and feeding trial}

The feeding trial was conducted at the Institut de Recerca i Tecnologia Agroalimentàries (IRTA, Sant Carles de la Rapita, Spain). European seabass (body weight, $\mathrm{BW}=2.0 \pm 0.2 \mathrm{~g}$ ) were obtained from Piscicultura Marina Mediterránea SL (Andromeda Group, Burriana, Valencia, Spain). They were fed a commercial feed (OptibassL-2, Skretting, Spain; 48.5\% of proteins, 16\% of lipids, $3.7 \%$ of fibers, $6.4 \%$ of ashes) for 2 weeks for them to acclimate to the experimental facilities. Then they were randomly distributed into twenty 500 -L fiberglass circular tanks ( 5 diets, 4 replicates per diet) at an initial density of $0.4 \mathrm{~kg} / \mathrm{m}^{3}$ (100 fish per tank). Before the feeding trial, sea bass were individually weighed for BW and measured for standard length (SL) $(B W=2.2 \pm 0.01 \mathrm{~g}$; $\mathrm{SL}=$ $5.1 \pm 0.04 \mathrm{~cm})$. During the study, average water temperature and $\mathrm{pH}$ ( $\mathrm{pH}$ meter 507; Crison Instruments), salinity (MASTER-20 T; ATAGO Co. Ltd) and dissolved $\mathrm{O}_{2}$ (OXI330; Crison Instruments) were $23.2 \pm$ $0.5{ }^{\circ} \mathrm{C}, 7.5 \pm 0.2,35.8 \pm 0.3 \mathrm{ppm}$ and $6.2 \pm 1.2 \mathrm{mg} / \mathrm{L}$, respectively. The water flow rate in the experimental tanks was maintained at approximately $9.0 \mathrm{~L} / \mathrm{min}$ by means of a recirculation system (IRTAmar ${ }^{\circ}$ that maintained adequate water quality (ammonia: $0.08 \pm 0.04 \mathrm{ppm}$, nitrites: $0.032 \pm 0.02 \mathrm{ppm}$ ) through UV, biological and mechanical filtration. The photoperiod followed seasonal changes (February-April; latitude $40^{\circ} 37^{\prime} 41^{\prime} \mathrm{N}$ ). Sea bass were fed in excess 6 times a day with automatic feeders (ARVO-TEC T Drum 2000 Finland) at a ration rate of $4.5 \% /$ day for 65 days. On day 31 , the BW of 50 fish per tank was recorded to adjust the daily feed ration.

At the end of the trial, we measured the BW and SL of all sea bass from each tank (the fish were fasted for $24 \mathrm{~h}$ prior to sampling). Specific Growth Rates (SGR), Fulton's condition factors (K), feed conversion ratio (FCR) and Survival Rates (SR) were calculated as follows: SGR (\% $\mathrm{BW} /$ day $)=100 \mathrm{x}[\ln$ final $\mathrm{BW}-\ln$ initial $\mathrm{BW}] /$ duration of the trial (days); $\mathrm{K}=\left[\mathrm{BW} / \mathrm{SL}^{3}\right] \times 100 ; \quad \mathrm{FCR}=[\mathrm{kg}$ diet consumed] $/[\mathrm{kg}$ final biomass $-\mathrm{kg}$ initial biomass $+\mathrm{kg}$ sampled fish + mortalities]; SR $(\%)=[$ number of fish at the end of the trial/initial number of fish] $\times 100$.

\section{Ethics statement}

All experimental procedures involving sea bass were conducted in compliance with the experimental research protocol approved by the Committee of Ethics and Animal Experimentation of the IRTA, the Departament Agricultura, Ramaderia, Pesca, Alimentació i Medi Natural (permit number 7962) and in accordance with the Guidelines of the European Union Council (86/609/ $\mathrm{EU})$ for the use of laboratory animals.

\section{Sample collection}

During handling and weighing, sea bass were anesthetized with $50 \mathrm{mg} / \mathrm{L}$ of MS-222 (Sigma Aldrich, Saint-Louis, MO, USA). At the end of the trial, they were sacrificed with an overdose of MS-222 $(100 \mathrm{mg} / \mathrm{mL})$ to collect the different tissues for analytical purposes. Sea bass were sampled on a cold plate $\left(0-4{ }^{\circ} \mathrm{C}\right)$, and the intestines from 15 individuals per diet were dissected and preserved in a $10 \%$ phosphate-formaldehyde buffer $(\mathrm{pH}=7.2)$ for histological purposes. In addition, the anterior intestine from nine fish per dietary treatment was sampled and immediately flash-frozen in liquid nitrogen for transcriptomic analysis. These samples were kept at $-80{ }^{\circ} \mathrm{C}$ until RNA extraction.

\section{Histological organization of the intestine}

After fixation, samples were dehydrated in a graded series of ethanol, cleared with xylene, embedded in 
paraffin (Histolab ZX-60 Myr, Medical Specialties MYR SL, Tarragona, Spain) and cut into serial sections $(2-3 \mu \mathrm{m}$ thick) (HM Microm, Leica Microsystems, Nussloch, Germany). Sections were stained with Hematoxin-Eosin for general histological descriptions, whereas slides were stained with Periodic Acid Schiff (PAS) and Alcian blue $(\mathrm{AB})$ at two different $\mathrm{pH}$ values (1.0 and 2.5) to stain different types of mucins produced by goblet cells [52]. PAS stains neutral mucins produced by intestinal goblet cells in magenta, whereas $A B$ weakly stains ionised sulphated glycoconjugates at $\mathrm{pH}=1.0$ and sialic acid at $\mathrm{pH}=2.5$. All sections were observed under a light microscope (Leica DM LB; Leica Microsystems) and photographed (Olympus DP70 Digital Camera; Olympus Imaging Europa GmbH, Hamburg, Germany). Digital images were processed and analyzed using ANALYSIS image analysis software package (Soft Imaging Systems GmbH). Total numbers of goblet cells (full and empty) and villi height were measured based on the analysis of eight to ten randomly chosen fields from the intestinal mucosa of 15 sea bass per diet. Goblet cell counts in intestinal villi were expressed over a contour length of $100 \mu \mathrm{m}$, whereas villi height and width were calculated according to the method of Escaffre et al. [53].

\section{Illumina sequencing}

Total RNAs from a pool of the proximal intestines of three sea bass from the same replicate tank were extracted separately. Tissues were homogenized (Mini-Beadbeater, Biospec Products Inc., USA) in $1 \mathrm{~mL}$ of TRIzol (Ambion, Life Technologies, Carlsbad, CA, USA), and solvent extraction was performed following the manufacturer's instructions. Final RNA concentrations were determined by spectrophotometry (NanoDrop 2000; Thermo Fisher Scientific, Waltham, Massachusetts, USA). RNA quality was assessed from $A_{260} / A_{280}$ ratios, and RNA integrity was assessed by denaturing gel electrophoresis. The three RNA samples from same replicate tank were then pooled before generating cDNA libraries. The total RNA concentration of each sample was quantified using a NanoDrop spectrophotometer (Thermo Fisher Scientific). cDNA libraries were built, and sequencing was performed as described in [54], with slight modifications. One $\mu \mathrm{g}$ of total RNA from each sample was initially used. dsDNAs were cleaved into 300-bp fragments using a Covaris S220 sonicator (Covaris Inc., Woburn, MA, USA) (duty cycle: $5 \%$, intensity 3, 200 bursts per second, duration: $50 \mathrm{~s}$ ). Eight pM of cDNA libraries per lane were loaded onto flow cells (Illumina Inc., San Diego, California, USA). The sequencing of $100-\mathrm{pb}$ paired-end reads was performed on an Illumina Miseq Sequencer at the SéSAME Platform (Centre de Lutte Contre le Cancer François Baclesse, Caen, France).

\section{Bioinformatic analysis}

Bioinformatic analysis was performed on RNA sequencing data from European seabass anterior intestine to study their physiological and molecular responses to dietary hydrolysate inclusion in a low fish meal diet. We tested 5 dietary conditions on the transcriptomic response of sea bass intestine: FM5 and FM20 diets as negative and positive control groups, respectively, and the $\mathrm{SH}, \mathrm{TH}$ and $\mathrm{MH}$ hydrolysate-based diets as experimental groups. The whole raw dataset was filtered and trimmed using Trimmomatic $\mathrm{v}(0.30)$ [55], using the following parameters: ILLUMINACLIP:adapter.fa:2:30:10, LEADING:5, TRAILING:5, SLIDING WINDOW:4:5, MINLEN:25. Global sequence quality was checked using FastQC (v 0.11.3) (https://www.bioinformatics.babraham.ac.uk/projects/fastqc). Global assembly was conducted using Trinity 2.1.1. [56], a dedicated package for de novo transcriptomics. A normalization step was conducted according to kmer coverage (kmer of $25 \mathrm{nt}$, maximum coverage of 30) proposed by the Trinity package. The inconsistent contigs generated by Trinity were removed after a remapping of reads using Bowtie (v 1.1.2) [57], and estimating relative abundance using RSEM [58] to get the FPKM values ( $\mathrm{v}$ 1.2.22) (the two software programs were launched through perl wrappers provided by the Trinity package). Finally, only transcripts with at least an FPKM value above 1 and isoforms corresponding to more than $1 \%$ of the total gene count were kept. Annotation of contig sequences was performed using both Blast2Go software [59] and the Trinotate pipeline (http://trinotate.github.io), as described in [60]. Sequences were blasted against the NCBI nr database (release 193) with the following set-up parameters: max BLAST hits 20, min Expect Value $10^{-3}$, and against the human proteome Ensembl database (release 82) (BLASTX). Only hits with E-values $<0.001$ were kept. Peptide prediction was performed using Transdecoder [60]. Similarity search (blastp of the Transdecoder-predicted peptides) was performed against the uniprot-swissprot database (release 2015-05). Peptide signal prediction was performed using signalP v4.1 [61]. Transmembrane peptide detection was performed using TMHMM v2.0c [62]. Protein domain search was performed using hmmscan from the hmmer v.3.1b1 suite against the Pfam-A database [63]. Finally, transcriptome functional annotation was performed using the Trinotate pipeline. A Gene Ontology (GO) classification was assigned to each predicted protein in BLASTX (E-Value hit: $10^{-6}$, annotation cut-off: 55 , GO weight: 5). Kyoto Encyclopedia of Genes and Genomes (KEGG) annotation was based on best BLASTX and PFAM search results.

\section{Differential expression analysis}

Differential gene expression between dietary treatments was identified using $\mathrm{R}$ software [64] and the DESeq2 
package [65]. Multiple testing was accounted for by controlling the false discovery rate (FDR) at 5\% using the Benjamini-Hochberg procedure. The RNA targets with adjusted $P$-values $<0.2$ and absolute fold changes $\geq 1.4$ were considered as differentially expressed. The relatively low stringency of the cut-off criteria is consistent with other nutrigenomic studies [48]. The impacts of hydrolysate diets on specific pathways were monitored using Ingenuity Pathway Analysis software (Qiagen, Hilden, Germany) with standard parameters. All annotated regulated genes were used.

\section{Statistics}

Final BW, SL and $\mathrm{K}$ results were expressed as mean \pm standard error of the mean (SEM) from all fish from each treatment. SGR, intestinal villi height, number of goblet cells, proximal composition and survival rates were expressed as mean \pm standard error of the mean (SEM) from the value of each replicate tank. All data were analyzed by one-way analysis of variance (ANOVA) followed by Tukey's test (normality and homogeneity of variances were previously checked). Differences were considered significant at $P<0.05$. For GO term comparison with Wego tool, Pearson Chi-Square tests were performed to show significant differences between diets $(P<0.05)[66]$.

\section{Results}

\section{Zootechnical performances}

Sea bass and feed performances are summarized in Table 1. At the end of the trial, dietary FM reduction (FM5 diet) had significantly impaired growth performances as compared to the positive control group (FM20) $(P<0.05)$. However, diets including protein hydrolysates (FM5 + 5\% TH, FM $5+5 \%$ SH and FM $5+5 \%$ $\mathrm{MH})$ significantly improved growth performances as compared to FM5 $(P<0.05)$ and allowed for similar growth performances as in sea bass fed the FM20 diet. The condition factor $(\mathrm{K})$ and the feed intake were not affected by dietary FM reduction or dietary hydrolysate inclusion $(P>0.05)$. Even if FCR values were slightly improved in fish fed dietary hydrolysates compared to negative control (FM5), the only statistical difference was between the negative and the positive controls $(P<0.05)$. Dietary treatments did not impact fish survival $(P>0.05)$.

\section{Histological examination}

Figure 1 shows the mean intestinal villi height of European seabass fed each diet. A significant decrease of villi height was observed in sea bass fed the FM5 diet as compared to the FM20 diet $(P<0.05)$. Inclusion of protein hydrolysates in the FM5 diet significantly increased intestinal villi height to reach values close to or even higher than in sea bass fed the FM20 diet $(P<0.05)$. The response of intestinal globlet cell density to dietary FM reduction and protein hydrolysate supplementation showed the same trend as intestinal villi height.

\section{Global overview of the RNA-seq}

The whole European seabass transcriptome project includes 108 Illumina libraries corresponding to the anterior intestine, but also the liver and kidney for each diet, for a total of 832,132,824 paired-end reads of $100 \mathrm{bp}$. Table 2 presents an overview of the sequencing project. Mapping was conducted both on the reference seabass genome (http://seabass.mpipz.de/DOWNLOADS/) and on the de novo assembled transcriptome from all samples, corresponding to 36 experimental conditions ( 6 diets * 3 tissues * 2 fish conditions) realized in triplicate.

Mapping scores were as follows: $83.55 \%$ for the mRNA extracted from the reference seabass genome annotation, and $92.77 \%$ for the de novo assembled transcriptome of the anterior intestine. In addition, the numbers of $\mathrm{DE}$ genes and annotations were higher with the de novo assembled transcriptome of the anterior intestine. Further differential expression analyses were then conducted on the global de novo transcriptome, composed of 56,246 transcripts after filtering with FPKM $<1$ and isoform $<1 \%$. The transcriptome corresponding to the total expression in

Table 1 Growth performances and survival rates of sea bass fed experimental diets over a 10-week period

\begin{tabular}{llllll}
\hline DIET & FM5 & FM20 & FM5 +5\% TH & FM5 +5\% SH & FM5 +5\% MH \\
\hline Initial BW (g) & $2.2 \pm 0.01$ & $2.2 \pm 0.01$ & $2.2 \pm 0.01$ & $2.3 \pm 0.00$ & $2.2 \pm 0.01$ \\
Final BW (g) & $11.7 \pm 0.4^{\mathrm{a}}$ & $13.1 \pm 0.3^{\mathrm{b}}$ & $13.9 \pm 0.4^{\mathrm{b}}$ & $13.2 \pm 0.5^{\mathrm{b}}$ & $13.0 \pm 0.6^{\mathrm{b}}$ \\
SGR (\%) & $2.5 \pm 0.1^{\mathrm{a}}$ & $2.7 \pm 0.1^{\mathrm{b}}$ & $2.8 \pm 0.1^{\mathrm{b}}$ & $2.7 \pm 0.1^{\mathrm{b}}$ & $2.7 \pm 0.1^{\mathrm{b}}$ \\
K factor & $2.0 \pm 0.03$ & $2.0 \pm 0.01$ & $2.0 \pm 0.02$ & $2.0 \pm 0.02$ & $2.0 \pm 0.03$ \\
Feed intake (g/kg ABW/d) & $33.34 \pm 1.46$ & $30.40 \pm 1.63$ & $31.55 \pm 1.41$ & $30.60 \pm 1.12$ & $31.50 \pm 0.94$ \\
FCR & $1.95 \pm 0.04^{\mathrm{a}}$ & $1.75 \pm 0.05^{\mathrm{b}}$ & $1.83 \pm 0.04^{\mathrm{ab}}$ & $1.79 \pm 0.04^{\mathrm{ab}}$ & $1.82 \pm 0.04^{\mathrm{ab}}$ \\
SR (\%) & $93.0 \pm 2.6$ & $96.0 \pm 0.9$ & $96.0 \pm 0.9$ & $93.8 \pm 0.8$ & $97.0 \pm 1.1$ \\
\hline
\end{tabular}

Values are the means of four replicate groups of 50 measurements each, presented as mean \pm SEM. Lines with different superscript letters differ significantly according to Tukey's multiple comparison test $(P<0.05)$. Abbreviations: $F M 55 \%$ fish meal diet, $F M 2020 \%$ fish meal diet; $T H$ tilapia hydrolysate diet, SH shrimp hydrolysate diet, $M H$ mixed hydrolysate diet, $B W$ body weight, $S G R$ specific growth rate, $A B W$ average body weight, $F C R$ feed conversion ratio, $S R$ survival rate 


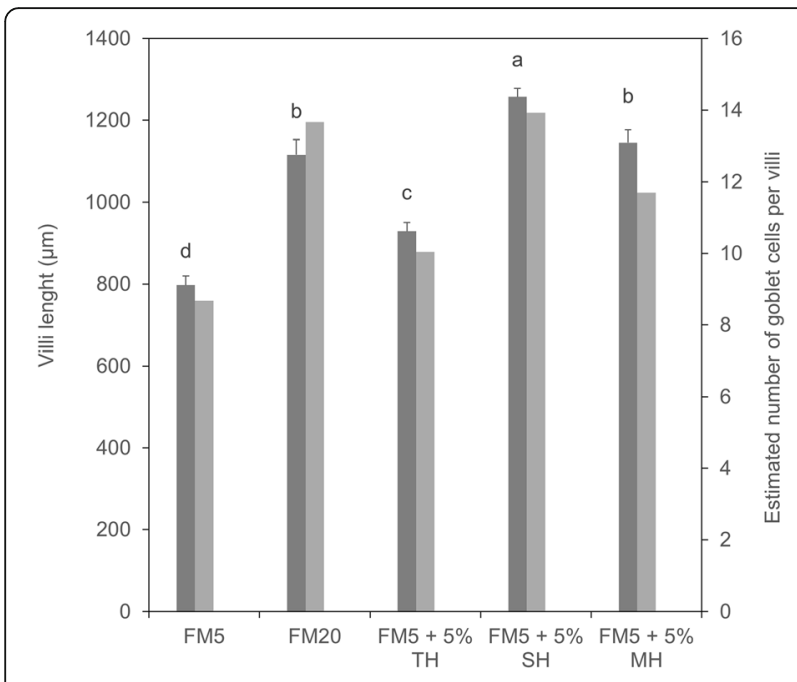

Fig. 1 Villi height and goblet cell density. Villi height values (dark grey) are the means of four replicate groups of 15 measurements each, presented as mean \pm SEM. Histograms with the same superscript letter did not differ significantly (Tukey's multiple comparison test, $P>0.05$ ). The number of goblet cells within $100 \mu \mathrm{m}$ of intestinal epithelium (grey) was calculated from 15 individuals per dietary group. FM5, 5\% fish meal diet; FM20, 20\% fish meal diet; $\mathrm{TH}$, tilapia hydrolysate diet; $\mathrm{SH}$, shrimp hydrolysate diet; $\mathrm{MH}$, mixed hydrolysate diet

Table 2 Overview of sequencing, assembly and annotation

\begin{tabular}{lll}
\hline Metrix & Unfiltered & Filtered \\
\hline Transcripts & 625,845 & 56,246 \\
Genes & 467,824 & 39,180 \\
GC\% & 44.28 & 44.13 \\
Median length (bp) & 389 & 910 \\
Average length (bp) & 922.7 & 1430.28 \\
Min (bp) & 201 & 201 \\
Max (bp) & 58,543 & 24,803 \\
Total number of bases & $577,467,800$ & $80,447,300$ \\
Annotation & & \\
Blastx hits with uniprot & 278,406 & 45,853 \\
Blastx hits with uniref90 & 377,852 & 46,552 \\
Blastp hits with uniprot & 227,499 & 41,578 \\
Blastp hits with uniref90 & 280,111 & 42,257 \\
Proteins with signal peptides & 20,540 & 2226 \\
Proteins with transmembrane helices & 28,482 & 5034 \\
Proteins with PFAM domains & 216,290 & 32,907 \\
Proteins with GO terms & 71,304 & 45,454 \\
Proteins with KEGG & 181,895 & 41,993 \\
\hline
\end{tabular}

Transcript filter: $<1$ FPKM, isoform $<1 \%$ the anterior intestinal mucosa was composed of 34,174 transcripts. More precisely, 99\% of total expression was present in 49,797 for the whole project and in 10,003 transcripts for the anterior intestinal mucosa respectively.

\section{Quantitative analysis of differential gene expression}

Differential gene expression analysis of RNA-seq data was performed to compare diets containing hydrolysates included to low (FM5) and high (FM20) fish meal diets. A total of 383 unique genes were differentially expressed (Table 3). Compared to the FM5 diet, 46 and 50 genes were differentially regulated by diets containing $\mathrm{TH}$ and $\mathrm{SH}$, respectively, and this number was higher in the FM20 (197) and MH (270) groups. Compared to the FM5 diet again, the distribution of differentially regulated genes between the FM20 diet and diets including hydrolysates indicated that $30.4 \%$ (14/46), 66.0\% (33/50), and $39.3 \%(106 / 270)$ of regulated genes were shared with the $\mathrm{TH}, \mathrm{SH}$ and $\mathrm{MH}$ diets, respectively. A total of 301 genes were only regulated by diets containing hydrolysates, but not by the FM20 diet, whereas some genes were regulated only by a specific hydrolysate diet. In particular, 19, 8, and 222 genes were specifically regulated by the $\mathrm{TH}, \mathrm{SH}$ and $\mathrm{MH}$ diets, respectively. Finally, the $\mathrm{TH}, \mathrm{SH}$ and $\mathrm{MH}$ diets induced gene expression patterns very similar to the FM20 diet pattern, with only 8,6 , and 6 genes differentially expressed among these dietary groups, respectively. The complete list and corresponding fold changes of regulated genes is provided in Additional files 2 and 3, for a comparison with the low-FM (FM5) and high-FM (FM20) diets, respectively.

\section{Identification of regulated genes}

GO term analysis revealed that dietary FM reduction, from 20 to $5 \%$, led to the regulation of a wide variety of genes involved in the metabolism, immunity, and tissue development of European seabass intestinal mucosa (Fig. 2).

$\mathrm{GO}$ term analysis of the genes regulated by hydrolysate-supplemented diets is presented in Fig. 3. The specific hydrolysates, which were influenced by by-product origin and the hydrolysis process, differentially impacted gene regulation $(P<0.05)$. In particular, under the TH diet, the level of GO term annotation was higher for the following categories: macromolecular complex, non-membrane-bounded organelle, intracellular non-membrane-bounded organelle, hydrolase activity, and ribonucleotide binding. In contrast, under the $\mathrm{SH}$ diet, the differentially regulated genes belonged mostly to the immune response and response to stimulus. Finally, under the $\mathrm{MH}$ diet, lipid metabolism-related $\mathrm{GO}$ terms were over-represented.

Based on GO term annotations, 74 differentially expressed transcripts were linked to nutrition as compared 
Table 3 Number of differently regulated genes as compared to the low (FM5) and high (FM20) fish meal diets

\begin{tabular}{|c|c|c|c|c|c|}
\hline $\mathrm{Nb}$ of regulated genes & FM5 & FM20 & $\mathrm{FM} 5+5 \% \mathrm{SH}$ & $\mathrm{FM} 5+5 \% \mathrm{TH}$ & $\mathrm{FM} 5+5 \% \mathrm{MH}$ \\
\hline vs. FM5 & - & 197 & 50 & 46 & 270 \\
\hline Shared with FM20 & & 197 & 33 & 14 & 106 \\
\hline Specifically regulated & - & 82 & 8 & 19 & 222 \\
\hline vs. FM20 & 197 & - & 8 & 6 & 6 \\
\hline
\end{tabular}

FM5 5\% fish meal diet, FM20 20\% fish meal diet, TH tilapia hydrolysate, SH shrimp hydrolysate, $M H$ mixed hydrolysate

to the FM5 diet: 15 transcripts related to digestion, 15 to carbohydrates, 7 to starvation, and 37 to carriers (Table 4). Treatments including tilapia hydrolysate ( $\mathrm{TH}$ and $\mathrm{MH}$ diets) impacted the expression of digestive enzyme and carbohydrate metabolism genes more deeply than the FM20 diet, although SH inclusion in the FM5 diet modulated a limited number of genes (5). Under the FM20 diet, carrier genes were over-expressed, except for a few related to lipid transport (apolipoproteins). Diet formulations induced specific regulations with $12,4,4$, and 32 transcripts differentially expressed by the FM20, $\mathrm{SH}, \mathrm{TH}$, and $\mathrm{MH}$ diets, respectively, as compared to FM5.

Table 5 presents regulated transcripts related to the cholesterol and long-chain fatty acid pathways. Lipid metabolism was modulated by the $\mathrm{MH}$ diet even more than by the FM20 diet. As compared to the FM5 diet, $15,0,3$, and 28 transcripts were differentially expressed by the FM20, TH, SH and MH diets, respectively. The $\mathrm{TH}$ diet did not impact the expression of the transcripts related to the cholesterol and long-chain fatty acid pathways.

Transcripts related to fish immunity and/or the stress response are presented in Table 6. As compared to the
FM5 diet, 20, 4, 12, and 36 transcripts were differentially expressed by the FM20, TH, $\mathrm{SH}$ and, $\mathrm{MH}$ diets, respectively. In contrast to the FM20 diet, all the diets containing hydrolysate down-regulated the expression of transcripts related to interferon. The diets containing one kind of hydrolysate ( $\mathrm{TH}$ or $\mathrm{SH}$ ) did not impact the regulation of histo-compatibility antigen-related genes, and only slightly impacted the serum complement- and cellular damage-related genes. Lectin-related gene expression was not affected by dietary $\mathrm{TH}$ inclusion.

\section{Impacted metabolic pathways}

We conducted various analyses to study the metabolic pathways impacted by dietary hydrolysates. Firstly, we performed a string analysis (https://string-db.org/cgi/ input.pl?) to reveal relationships between regulated genes and a defined enrichment (Additional file 4). Regarding the TH diet, 11 genes, distributed into 3 groups, were interconnected, but no enrichment was observed. In the case of the $\mathrm{SH}$ diet, 11 regulated genes formed 2 groups, but without inducing overexpression of any specific metabolic pathway. Six regulated genes were common to the $\mathrm{TH}$ and $\mathrm{SH}$ diets (cebpd, cebpb, rsad2,

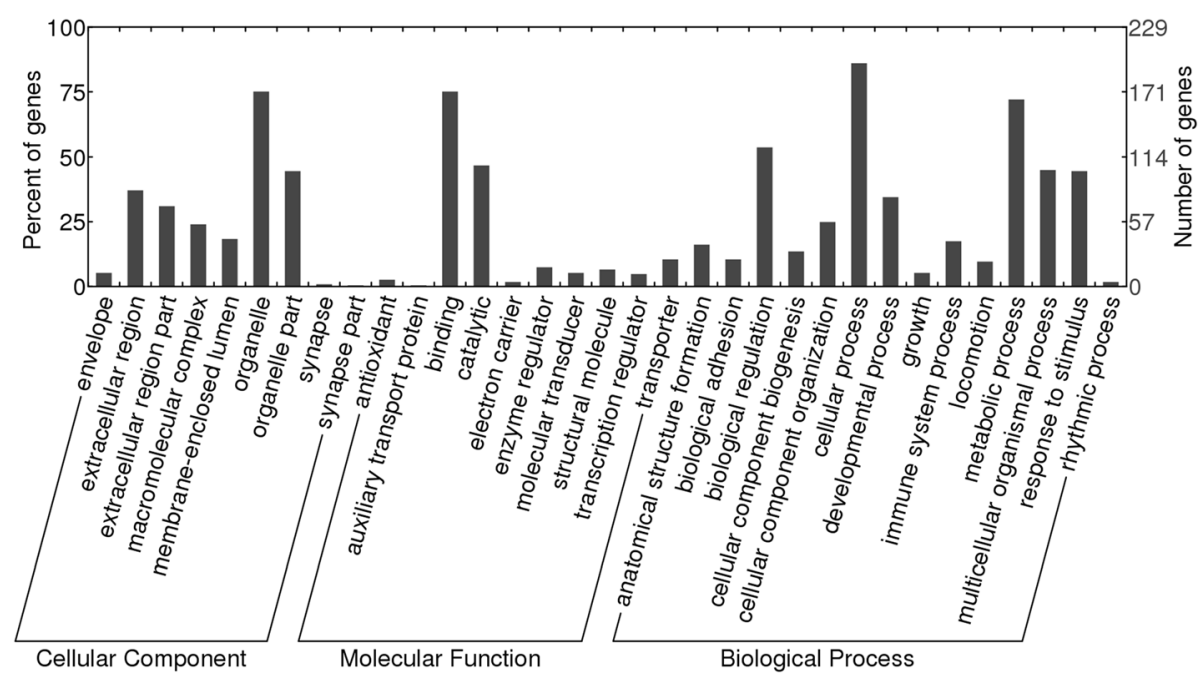

Fig. 2 GO term analysis of regulated genes from the anterior intestinal mucosa of European seabass fed diets containing low FM diet (FM5) as compared to sea bass fed a high FM diet (FM20) 


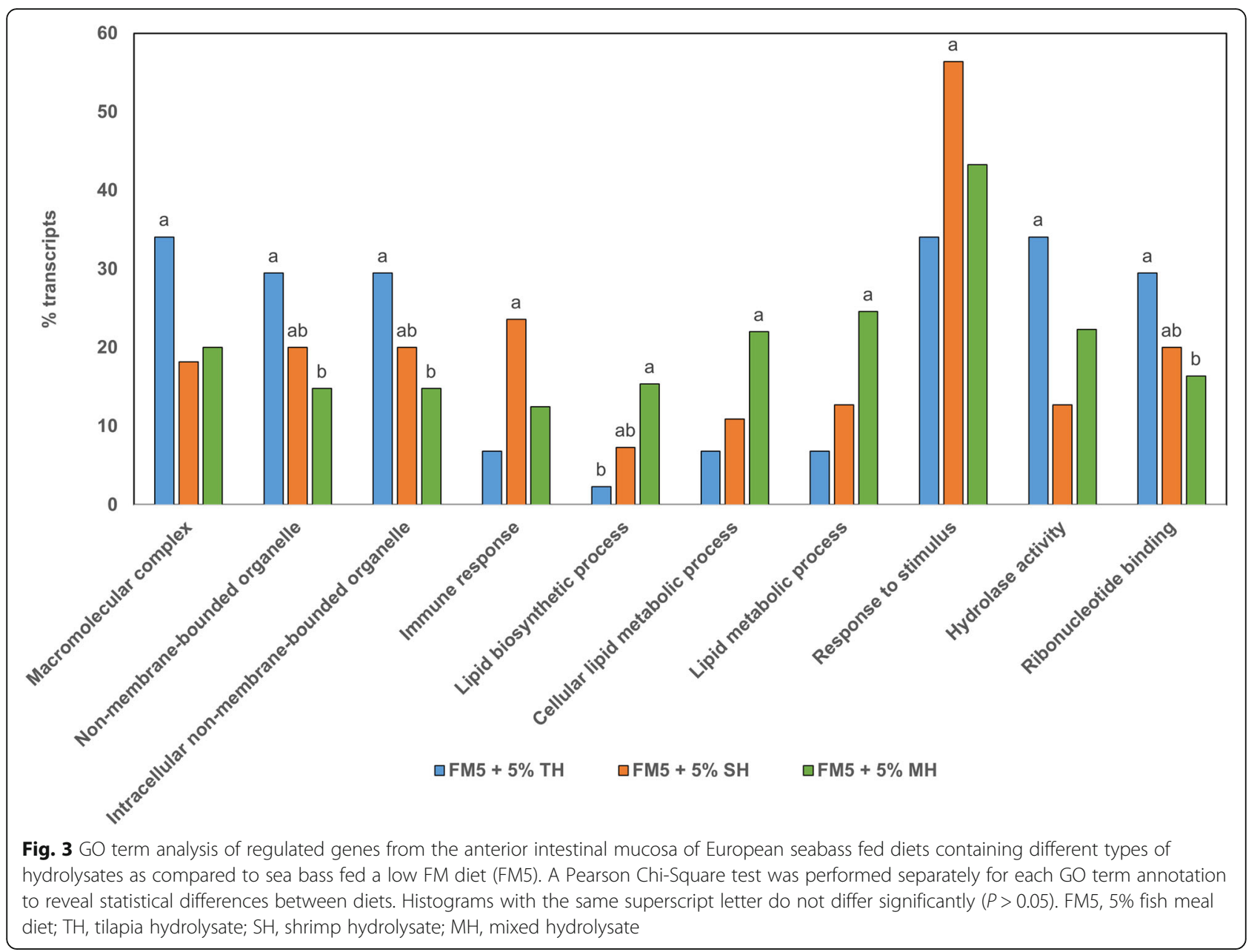

herc6, $m \times 1$ and cmpk2). The g6pc, aldob, eif2ak4, ace, apob and hba1, scn $2 a$, junb, fdp5, dhx58 genes were connected to the $\mathrm{TH}$ and $\mathrm{SH}$ diets, respectively. Under the $\mathrm{MH}$ diet, many more regulated genes were connected (87), with the ACLY gene at the center of the gene network. The enrichment scores calculated for biological processes, molecular functions, cellular component and KEGG pathways are shown in Table 7 . The main enrichments for biological processes were the following: small molecule metabolic process, cellular lipid metabolic process, lipid metabolic process, organophosphate metabolic process, single-organism catabolic process; cellular components were cytosol, cytoplasmic part, membrane-bounded vesicle, extracellular exosome, and extracellular region part; whereas molecular functions were catalytic activity, ethanolamine kinase activity, oxidoreductase activity, cofactor binding, coenzyme binding, and KEGG metabolic pathways were steroid biosynthesis, fat digestion and absorption, glycerophospholipid metabolism, and glycolysis/gluconeogenesis.
A KEGG analysis based on KEGG orthology annotation showed that the main impacted pathways differed depending on the origin of the dietary hydrolysate (Table 8). In particular, 9, 9, and 55 differentially regulated genes participated to metabolic pathways (KO: 01100) in response to the $\mathrm{TH}, \mathrm{SH}$, and $\mathrm{MH}$ diets, respectively. To be more precise, the metabolic pathways impacted by the TH diet mainly influenced carbohydrate metabolism, whereas the SH diet impacted the nucleotide metabolism and terpenoid backbone biosynthesis. In addition to these metabolic pathways, defense and immunity pathways were also affected by hydrolysate inclusion to the diet. The complete list of impacted pathways and corresponding genes is available in Additional file 5.

We also investigated the pathways regulated by dietary treatments using Ingenuity Pathway Analysis Software. Results are summarized in Table 9, focusing on the top canonical pathways as well as on molecular and cellular functions. The main metabolic pathways impacted by dietary hydrolysates were the ones related to the 
Table 4 Summary of differentially expressed genes related to nutrition

\begin{tabular}{|c|c|c|c|c|c|}
\hline \multirow[t]{2}{*}{ Classification/Transcript } & \multirow[t]{2}{*}{ Name (best blast) } & \multicolumn{4}{|c|}{$\begin{array}{l}\text { Gene fold change as compared to the low fish } \\
\text { meal diet (FM5) }\end{array}$} \\
\hline & & FM20 & $\mathrm{FM} 5+5 \% \mathrm{TH}$ & $\mathrm{FM} 5+5 \% \mathrm{SH}$ & $\mathrm{FM} 5+5 \% \mathrm{MH}$ \\
\hline \multicolumn{6}{|l|}{ Digestion related } \\
\hline TRINITY DN79635 c16 g28 & 2-phosphoxylose phosphatase 1 & -1.85 & & & \\
\hline TRINITY DN74666 c1 g3 & Aminopeptidase N & 1.97 & & & 2.92 \\
\hline TRINITY DN74666 c0 g1 & Aminopeptidase N & & & & 2.80 \\
\hline TRINITY DN76691 c3 g3 & Chymotrypsin-C & & 2.30 & & \\
\hline TRINITY DN66951 c0 g2 & Dipeptidase 1 & & & & 2.68 \\
\hline TRINITY DN75551 c3 g1 & Dipeptidyl peptidase 4 & 1.68 & & & 1.96 \\
\hline TRINITY DN71008 c5 g1 & Meprin A subunit alpha & 1.54 & & & \\
\hline TRINITY DN72685 c5 g4 & Meprin A subunit beta & 1.90 & & & 2.07 \\
\hline TRINITY DN75683 c2 g1 & Meprin A subunit beta & 1.64 & 1.98 & & 2.04 \\
\hline TRINITY DN6986 c0 g1 & Pepsin A & & 3.11 & 2.7 & 4.79 \\
\hline TRINITY DN78404 c2 g1 & Phospholipase B1, membrane-associated & & & & 3.61 \\
\hline TRINITY DN77910 c4 g1 & Phospholipase B1, membrane-associated & & & & 4.33 \\
\hline TRINITY DN56338 c0 g1 & Trypsinogen-like protein 3 & & & & -1.90 \\
\hline TRINITY DN74387 c3 g1 & Xaa-Pro aminopeptidase 2 & 2.26 & & & 2.61 \\
\hline TRINITY DN75167 c0 g2 & Xaa-Pro dipeptidase & & & & 1.72 \\
\hline \multicolumn{6}{|l|}{ Carbohydrate related } \\
\hline TRINITY DN74193 c6 g1 & 2-oxoglutarate dehydrogenase, mitochondrial & 1.82 & & & \\
\hline TRINITY DN73012 c2 g2 & ADP-dependent glucokinase & & & & -2.19 \\
\hline TRINITY DN77048 c0 g5 & Beta-galactosidase & & & & -2.18 \\
\hline TRINITY DN77546 c2 g14 & Beta-hexosaminidase subunit beta & & & & 3.15 \\
\hline TRINITY DN76262 c5 g1 & $\begin{array}{l}\text { CMP-N-acetylneuraminate-beta-galactosamide-alpha-2,3- } \\
\text { sialyltransferase } 2\end{array}$ & 6.76 & & 5.3 & 6.90 \\
\hline TRINITY DN76669 c2 g6 & $\begin{array}{l}\text { CMP-N-acetylneuraminate-beta-galactosamide-alpha-2,3- } \\
\text { sialyltransferase } 4\end{array}$ & 2.40 & & & \\
\hline TRINITY DN67442 c0 g3 & Fructose-1,6-bisphosphatase 1 & & 1.99 & & \\
\hline TRINITY DN79451 c1 g1 & Fructose-bisphosphate aldolase B & & 2.05 & & 2.17 \\
\hline TRINITY DN77757 c0 g1 & Glucose-6-phosphatase & & & & 2.48 \\
\hline TRINITY DN78836 c3 g3 & Glucose-6-phosphatase & & 2.99 & & 3.71 \\
\hline TRINITY DN77732 c1 g2 & Lysosomal alpha-mannosidase & & & & 2.13 \\
\hline TRINITY DN75851 c2 g4 & Maltase-glucoamylase, intestinal & 2.10 & 2.31 & & 3.03 \\
\hline TRINITY DN75571 c0 g1 & Phosphoenolpyruvate carboxykinase, cytosolic [GTP] & 1.70 & & & 2.34 \\
\hline TRINITY DN66475 c0 g1 & UDP-glucose 4-epimerase & -2.69 & & & -2.53 \\
\hline TRINITY DN75517 c0 g1 & UDP-glucose 6-dehydrogenase & & & & -4.48 \\
\hline \multicolumn{6}{|l|}{ Starvation related } \\
\hline TRINITY DN71986 c0 g1 & Angiopoietin-related protein 4 & -1.71 & & & -2.88 \\
\hline TRINITY DN65255 c0 g1 & Collectrin & & & & 4.96 \\
\hline TRINITY DN69741 c0 g2 & DEP domain-containing mTOR-interacting protein & 2.10 & & & 1.87 \\
\hline TRINITY DN79325 c3 g4 & Folliculin-interacting protein 1 & 1.69 & & & \\
\hline TRINITY DN53239 c0 g1 & Neuropeptide $Y$ & & & & -3.68 \\
\hline TRINITY DN59469 c0 g1 & Neuropeptide YY-A & & & & -2.59 \\
\hline TRINITY DN76722 c3 g1 & Serine/threonine-protein kinase ULK2 & 2.57 & & & \\
\hline
\end{tabular}


Table 4 Summary of differentially expressed genes related to nutrition (Continued)

\begin{tabular}{|c|c|c|c|c|c|}
\hline \multirow[t]{2}{*}{ Classification/Transcript } & \multirow[t]{2}{*}{ Name (best blast) } & \multicolumn{4}{|c|}{$\begin{array}{l}\text { Gene fold change as compared to the low fish } \\
\text { meal diet (FM5) }\end{array}$} \\
\hline & & FM20 & $\mathrm{FM} 5+5 \% \mathrm{TH}$ & $\mathrm{FM} 5+5 \% \mathrm{SH}$ & $\mathrm{FM} 5+5 \% \mathrm{MH}$ \\
\hline \multicolumn{6}{|l|}{ Carrier } \\
\hline TRINITY DN79318 c11 g9 & 14 kDa apolipoprotein & -1.64 & & & -2.91 \\
\hline TRINITY DN79318 c11 g7 & 14 kDa apolipoprotein & -1.79 & & & -2.92 \\
\hline TRINITY DN69453 c0 g1 & Apolipoprotein A1/A4/E domain (pfam) & -3.09 & & & -7.19 \\
\hline TRINITY DN71711 c0 g1 & Apolipoprotein A-IV & -2.02 & & & -2.84 \\
\hline TRINITY DN70740 c0 g1 & Apolipoprotein A-IV & -3.28 & & -2.1 & -5.05 \\
\hline TRINITY DN79385 c0 g8 & Apolipoprotein B-100 & & 2.57 & & \\
\hline TRINITY DN73752 c8 g3 & Apolipoprotein C-I (ApoC-1) pfam & & & & -3.87 \\
\hline TRINITY DN78962 c1 g23 & Apolipoprotein C-II (pfam) & & & & -2.29 \\
\hline TRINITY DN78962 c1 g36 & Apolipoprotein C-II (pfam) & -1.66 & & & -2.54 \\
\hline TRINITY DN78793 c2 g9 & Apolipoprotein Eb & & & & -4.81 \\
\hline TRINITY DN63420 c0 g2 & Aquaporin FA-CHIP & & & & 2.00 \\
\hline TRINITY DN76968 c1 g2 & Asc-type amino acid transporter 1 & 1.70 & & & \\
\hline TRINITY DN70677 c12 g4 & ATP-binding cassette sub-family A member 1 & & & & 1.98 \\
\hline TRINITY DN78213 c1 g1 & Chloride anion exchanger & & & & 2.74 \\
\hline TRINITY DN68770 c0 g2 & Chloride intracellular channel protein 4 & & & & 2.01 \\
\hline TRINITY DN67686 c1 g1 & Chloride intracellular channel protein 5 & & & & 1.77 \\
\hline TRINITY DN69002 c1 g2 & Large neutral amino acids transporter small subunit 4 & & & & 1.96 \\
\hline TRINITY DN79534 c0 g1 & MLN64 N-terminal domain homolog & & & & 2.39 \\
\hline TRINITY DN75016 c2 g2 & Monocarboxylate transporter 12-B & & & & 1.81 \\
\hline TRINITY DN71474 c7 g3 & $\mathrm{Na}(+) / \mathrm{H}(+)$ exchange regulatory cofactor NHE-RF1 & & & & 2.64 \\
\hline TRINITY DN74500 c2 g1 & $\mathrm{Na}(+) / \mathrm{H}(+)$ exchange regulatory cofactor NHE-RF3 & & & & 1.94 \\
\hline TRINITY DN79418 c0 g1 & Niemann-Pick C1-like protein 1 & & & & 2.65 \\
\hline TRINITY DN76301 c3 g1 & Niemann-Pick C1-like protein 1 & & & & 1.85 \\
\hline TRINITY DN75948 c4 g4 & Phospholipid-transporting ATPase IA & 2.26 & & & \\
\hline TRINITY DN75214 c1 g9 & Prolyl endopeptidase-like & & & & 1.85 \\
\hline TRINITY DN77239 c2 g2 & Sodium/hydrogen exchanger 7 & & & & 4.65 \\
\hline TRINITY DN67206 c1 g1 & Sodium/myo-inositol cotransporter & -3.06 & & & -3.55 \\
\hline TRINITY DN67731 c1 g1 & Sodium/potassium-transporting ATPase subunit alpha-1 & & 2.22 & & 2.99 \\
\hline TRINITY DN79640 c8 g1 & Sodium-dependent neutral amino acid transporter B(0)AT1 & 2.83 & & 2.7 & 3.96 \\
\hline TRINITY DN71667 c2 g2 & Sodium-dependent phosphate transport protein $2 \mathrm{~B}$ & & & 2.3 & 3.25 \\
\hline TRINITY DN69556 c1 g3 & Solute carrier family 13 member 2 & 2.15 & & & 2.78 \\
\hline TRINITY DN60850 c0 g1 & Solute carrier family 13 member 5 & 2.34 & & 2.1 & 2.73 \\
\hline TRINITY DN68059 c1 g4 & Solute carrier family 15 member 1 & & 1.78 & & \\
\hline TRINITY DN73228 c5 g1 & Solute carrier family 2, facilitated glucose transporter member 2 & & & & 2.56 \\
\hline TRINITY DN72783 c3 g1 & Solute carrier family 22 member 6 & & -3.83 & & \\
\hline TRINITY DN79648 c5 g9 & Solute carrier family 40 member 1 & & & & 2.60 \\
\hline TRINITY DN73224 c8 g2 & Zinc transporter 1 & & & & 2.54 \\
\hline
\end{tabular}

Values correspond to fold changes between diets and the low fish meal control diet. Positive values indicate upregulation, and negative values down regulation. FM5 5\% fish meal diet, FM20 20\% fish meal diet, TH tilapia hydrolysate diet, SH shrimp hydrolysate diet, MH mixed hydrolysate diet 
Table 5 Summary of differentially expressed genes related to cholesterol and long chain fatty acid pathways

\begin{tabular}{|c|c|c|c|c|c|}
\hline \multirow[t]{2}{*}{ Classification/Transcript } & & \multicolumn{4}{|c|}{$\begin{array}{l}\text { Gene fold change as compared to the low fish meal diet } \\
\text { (FM5) }\end{array}$} \\
\hline & & FM20 & $\mathrm{FM} 5+5 \% \mathrm{TH}$ & $\mathrm{FM} 5+5 \% \mathrm{SH}$ & $\mathrm{FM} 5+5 \% \mathrm{MH}$ \\
\hline \multicolumn{6}{|l|}{ Cholesterol related } \\
\hline TRINITY DN71881 c0 g2 & 3-beta-hydroxysteroid-Delta(8),Delta(7)-isomerase & & & & -3.00 \\
\hline TRINITY DN67458 c2 g3 & Delta(14)-sterol reductase & & & & -2.75 \\
\hline TRINITY DN76391 c4 g1 & Farnesyl pyrophosphate synthase & -2.98 & & -2.7 & -5.68 \\
\hline TRINITY DN71950 c2 g1 & Hydroxymethylglutaryl-CoA synthase, cytoplasmic & -1.93 & & & -3.19 \\
\hline TRINITY DN79342 c1 g2 & Lanosterol 14-alpha demethylase & -1.85 & & & -2.06 \\
\hline TRINITY DN75940 c1 g2 & Lanosterol synthase & -2.65 & & & -3.74 \\
\hline TRINITY DN76284 c0 g1 & Lathosterol oxidase & & & & -2.68 \\
\hline TRINITY DN72542 c3 g1 & Neutral cholesterol ester hydrolase 1 & 2.61 & & & \\
\hline TRINITY DN66926 c0 g1 & Squalene monooxygenase & & & & -3.82 \\
\hline TRINITY DN78143 c3 g1 & Squalene synthase & & & & -2.64 \\
\hline TRINITY DN71672 c0 g3 & Sterol-4-alpha-carboxylate 3-dehydrogenase, decarboxylating & & & & -3.59 \\
\hline TRINITY DN75298 c0 g2 & Transmembrane protein 97 & & & & -2.25 \\
\hline \multicolumn{6}{|l|}{ Fatty acid related } \\
\hline TRINITY DN70866 c4 g9 & 2,4-dienoyl-CoA reductase, mitochondrial & & & & -1.92 \\
\hline TRINITY DN78203 c0 g3 & 3-ketoacyl-CoA thiolase, mitochondrial & & & & -2.37 \\
\hline TRINITY DN74534 c0 g3 & Acetoacetyl-CoA synthetase & & & & -4.95 \\
\hline TRINITY DN74255 c1 g3 & Acetyl-CoA carboxylase & & & & -2.11 \\
\hline TRINITY DN72189 c4 g3 & Acyl-CoA desaturase & 1.78 & & & 5.40 \\
\hline TRINITY DN70036 c1 g2 & Alkylglycerol monooxygenase & 1.99 & & & \\
\hline TRINITY DN77637 c3 g4 & ATP-binding cassette sub-family D member 2 & & & & -3.41 \\
\hline TRINITY DN74635 c4 g2 & Elongation of very long chain fatty acids protein 4 & & & & -2.71 \\
\hline TRINITY DN73852 c1 g2 & Elongation of very long chain fatty acids protein 6 & & & & -3.96 \\
\hline TRINITY DN79046 c1 g4 & Fatty acid hydroxylase domain-containing protein 2 & & & & 1.94 \\
\hline TRINITY DN79053 c1 g4 & Fatty acid synthase & & & & -3.33 \\
\hline TRINITY DN79341 c1 g1 & Fatty acid-binding protein, brain & 4.26 & & & \\
\hline TRINITY DN56507 c0 g1 & Fatty acid-binding protein, intestinal & & & & -1.88 \\
\hline TRINITY DN79266 c1 g10 & Fatty acid-binding protein, liver-type & & & & -2.17 \\
\hline TRINITY DN78522 c0 g2 & Long-chain-fatty-acid-CoA ligase 4 & -1.89 & & & \\
\hline TRINITY DN75220 c0 g3 & Methylsterol monooxygenase 1 & -2.26 & & & -2.31 \\
\hline TRINITY DN78695 c0 g7 & Perilipin-2 & -3.04 & & & \\
\hline TRINITY DN78695 c0 g2 & Perilipin-2 & -3.15 & & -2.3 & \\
\hline TRINITY DN72627 c0 g1 & Phosphatidate phosphatase LPIN1 & & & & -4.12 \\
\hline TRINITY DN72627 c1 g3 & Phosphatidate phosphatase LPIN2 & 2.00 & & & \\
\hline TRINITY DN71726 c1 g1 & Sodium-dependent lysophosphatidylcholine symporter 1-B & & & & -3.38 \\
\hline TRINITY DN72471 c1 g2 & Trifunctional enzyme subunit beta, mitochondrial & & & & -2.18 \\
\hline TRINITY DN67880 c1 g2 & Very long-chain acyl-CoA synthetase & & & 2.1 & 3.01 \\
\hline TRINITY DN71905 c5 g2 & Very long-chain acyl-CoA synthetase & 1.93 & & & \\
\hline TRINITY DN76293 c0 g2 & Very long-chain acyl-CoA synthetase & 1.87 & & & \\
\hline
\end{tabular}

Values correspond to fold changes between diets and the low fish meal control diet. Positive values indicate upregulation, and negative values down regulation. FM5 5\% fish meal diet, FM20 20\% fish meal diet, TH tilapia hydrolysate diet, SH shrimp hydrolysate diet, $M H$ mixed hydrolysate diet 
Table 6 Summary of differentially expressed genes related to fish health status

\begin{tabular}{|c|c|c|c|c|c|}
\hline \multirow[t]{2}{*}{ Classification/Transcript } & \multirow[t]{2}{*}{ Name (best blast) } & \multicolumn{4}{|c|}{$\begin{array}{l}\text { Gene fold change as compared to the low fish } \\
\text { meal diet (FM5) }\end{array}$} \\
\hline & & FM20 & $\mathrm{FM} 5+5 \% \mathrm{TH}$ & $\mathrm{FM} 5+5 \% \mathrm{SH}$ & $\mathrm{FM} 5+5 \% \mathrm{MH}$ \\
\hline \multicolumn{6}{|l|}{ Interferon related } \\
\hline TRINITY DN69994 c1 g3 & Gamma-interferon-inducible lysosomal thiol reductase & & & & 2.39 \\
\hline TRINITY DN67652 cl g1 & Interferon alpha-inducible protein 27-like protein 2A & & & -2.2 & -2.22 \\
\hline TRINITY DN78765 c2 g3 & Interferon stimulated gene 15 & & & -3.4 & \\
\hline TRINITY DN78866 c1 g8 & Interferon-induced GTP-binding protein Mx & & -2.72 & & -2.56 \\
\hline TRINITY DN78866 c1 g9 & Interferon-induced GTP-binding protein Mx & & -3.37 & -2.7 & -2.41 \\
\hline TRINITY DN78532 c1 g14 & Interferon-inducible protein 56 & & & -2.3 & -2.23 \\
\hline \multicolumn{6}{|c|}{ Histocompatibility antigen related } \\
\hline TRINITY DN79419 c7 g6 & Class I histocompatibility antigen, B alpha chain & 1.95 & & & 2.98 \\
\hline TRINITY DN79651 c13 g9 & $\mathrm{H}^{-2}$ class I histocompatibility antigen, $\mathrm{K}-\mathrm{K}$ alpha chain & & & & 3.85 \\
\hline TRINITY DN78477 c2 g7 & H-2 class II histocompatibility antigen gamma chain & 1.95 & & & 2.74 \\
\hline TRINITY DN72971 c0 g4 & Rano class II histocompatibility antigen, A beta chain & 2.20 & & & 2.45 \\
\hline TRINITY DN72971 c0 g3 & Rano class II histocompatibility antigen, A beta chain & & & & 3.32 \\
\hline \multicolumn{6}{|l|}{ Lectin related } \\
\hline TRINITY DN69402 c2 g1 & Fucolectin & 4.15 & & 3.9 & 5.35 \\
\hline TRINITY DN69402 c2 g2 & Fucolectin & 6.15 & & 2.9 & 7.67 \\
\hline TRINITY DN65160 c0 g3 & Fucolectin-1 & 2.46 & & & 3.39 \\
\hline TRINITY DN65160 c0 g4 & Fucolectin-1 & & & 4.2 & 7.27 \\
\hline TRINITY DN78379 c3 g2 & Fucolectin-1 & & & & 5.03 \\
\hline TRINITY DN78379 c3 g7 & Fucolectin-1 & 2.54 & & & 2.38 \\
\hline TRINITY DN69906 c1 g1 & Nattectin & & & & 3.37 \\
\hline \multicolumn{6}{|l|}{ Pentraxin related } \\
\hline TRINITY DN77743 c1 g13 & C-reactive protein & & & 2.9 & \\
\hline TRINITY DN77743 c1 g7 & C-reactive protein & 3.73 & 3.25 & 2.5 & 4.47 \\
\hline TRINITY DN14972 c0 g1 & Serum amyloid P-component & 5.12 & & 2.8 & 5.87 \\
\hline \multicolumn{6}{|l|}{ Serum complement related } \\
\hline TRINITY DN60272 c0 g1 & C1q domain (pfam) & 1.53 & & & \\
\hline TRINITY DN60272 c0 g1 & C1q domain (pfam) & 1.53 & & & \\
\hline TRINITY DN78829 c1 g1 & C1q domain (pfam) & 3.53 & & & 4.69 \\
\hline TRINITY DN77811 c0 g3 & C1q domain (pfam) & & & & 2.91 \\
\hline TRINITY DN73741 c7 g14 & C1q-like 23 kDa protein & & 6.85 & & \\
\hline TRINITY DN67406 c0 g1 & C1q-like 23 kDa protein & 7.94 & & & 10.81 \\
\hline TRINITY DN79561 c2 g21 & C1q-like 23 kDa protein & 6.25 & & & 10.35 \\
\hline \multicolumn{6}{|l|}{ TNF-a related } \\
\hline TRINITY DN59663 c0 g1 & Tumor necrosis factor alpha-induced protein 8-like protein 3 & & & & 2.31 \\
\hline TRINITY DN75139 c4 g2 & Tumor necrosis factor ligand superfamily member 10 & 2.20 & & 2.3 & 3.09 \\
\hline TRINITY DN69734 c2 g1 & Tumor necrosis factor receptor superfamily member $11 \mathrm{~A}$ & & & & 2.82 \\
\hline \multicolumn{6}{|l|}{ Cellular stress related } \\
\hline TRINITY DN71217 c2 g2 & Glutathione peroxidase 2 & & & & -2.58 \\
\hline TRINITY DN79626 c5 g2 & Phospholipid hydroperoxide glutathione peroxidase, mitochondrial & -2.21 & & & -3.81 \\
\hline TRINITY DN79626 c5 g6 & Phospholipid hydroperoxide glutathione peroxidase, mitochondrial & & & & -3.27 \\
\hline TRINITY DN79626 c5 g1 & Phospholipid hydroperoxide glutathione peroxidase, mitochondrial & -2.56 & & & -4.22 \\
\hline
\end{tabular}


Table 6 Summary of differentially expressed genes related to fish health status (Continued)

\begin{tabular}{llll}
\hline Classification/Transcript & Name (best blast) & \multicolumn{2}{l}{$\begin{array}{l}\text { Gene fold change as compared to the low fish } \\
\text { meal diet (FM5) }\end{array}$} \\
\cline { 3 - 4 } & & FM20 FM5 +5\% TH & FM5 + 5\% SH FM5 +5\% MH \\
\hline TRINITY DN76439 c4 g1 & Gamma-glutamyltranspeptidase 1 & 2.72 & 4.40 \\
TRINITY DN63786 c0 g2 & Sestrin-1 & & 2.12 \\
TRINITY DN77226 c0 g3 & Selenocysteine lyase & -6.45 & -3.08 \\
TRINITY DN68233 c1 g1 & DNA damage-inducible transcript 4-like protein & -2.82 & -3.2 \\
TRINITY DN77069 c1 g2 & DNA repair protein complementing XP-A cells homolog & & -3.41 \\
TRINITY DN76110 c0 g10 & Tyrosyl-DNA phosphodiesterase 2 & & -2.64 \\
\hline
\end{tabular}

Values correspond to fold changes between diets and the low fish meal control diet. Positive values indicate upregulation, and negative values down regulation. FM5 5\% fish meal diet, FM20 20\% fish meal diet, $T H$ tilapia hydrolysate diet, SH shrimp hydrolysate diet, $M H$ mixed hydrolysate diet

carbohydrate and lipid metabolisms. Complete results are available in Additional file 6.

\section{Discussion}

Impact of hydrolysate inclusion in a low FM diet on European seabass growth performances and histological organization of the intestine mucosa

Our results showed that a 15\% decrease of dietary FM negatively affected the growth performances of European seabass as compared to the $20 \%$ FM control diet. These findings are consistent with other studies about other carnivorous fish species [12, 67-69]. However, dietary inclusion of $5 \%$ of protein hydrolysate restored growth performances to the same level as the FM20 control diet. These positive effects of dietary hydrolysates are in agreement with other studies about fish fed diets incorporating such ingredients [29, 32, 38].

Feed intake was not modified by diets as fish were fed in excess to guarantee a high consumption. Feed conversion ratio improvement of fish fed the FM20 diet compared to the FM5 diet could be the result of a better nutritional balance of the diet combined to a better feed consumption. Dietary inclusion of hydrolysate allowed to recover a good feed intake as well as to improve enough feed efficiency to reach fish and feed performance very closed to the positive control. The high degree of protein hydrolysis of our hydrolysates [37, 40], resulting in enrichment of the feed with highly palatable and digestible low-molecular-weight peptides and free amino acids, could explain why growth performances were improved. However, fish growth performances should not be the single criterion to evaluate the performance of a new aquafeed formula. It is also necessary to study the response of fish metabolism to ensure that modifications in the diet will not induce significant metabolic disturbances that could affect fish resistance to their environment. Maintaining the integrity of fish intestines is of critical concern when considering the performance of aquaculture feeds. Many studies have shown that enteritis events can occur when carnivorous fish are fed feeds formulated with high levels of plant-based proteins [17, 70-74]. A direct consequence of enteritis is deterioration of feed utilization and of the fish health status. The intestine is involved not only in digestion and feed absorption, but also in water and electrolyte balance, nutrient sensing, and immunity. This functional diversity is currently being elucidated in fish, and different histological and molecular approaches are helping to understand the many vital functions conducted along the gastrointestinal tract [46]. The general organization and morphometric parameters of the intestine, represented by villi size and the number of goblet cells, are good indicators of the health and condition of the fish intestinal mucosa: an increase of intestinal villi size reflects an improvement of the exchange surface, of the activity of the brush border enzymes and of the nutrient transport systems, with positive effects on digestion and absorption [75]. In addition, in rainbow trout $(O$. mykiss) goblet cells regulate proteins or peptides as well as ion and fluid transport, and also provide an effective immune barrier against potentially pathogenic gut bacteria $[47,76]$. Furthermore, enhanced mucin production by increased goblet cell populations physically displaces potentially pathogenic organisms, a more diverse microbiota leads to a thickening of the mucus layer, and this improves gut microniches inhabited by these beneficial bacteria [77]. In the present study, we demonstrate that European seabass fed a diet containing low fish meal levels (FM5) had an altered intestinal mucosa. These results are consistent with other studies that showed a decrease in villi height [39, 72, 78-80] and/or in the number of goblet cells $[38,39]$ in fish fed the low FM diet. Incorporation of hydrolysates at a relatively low inclusion rate $(5 \%)$ in the low FM formula (FM5) improved the histological organization of the intestinal mucosa, with villi heights close to those observed in the control group (FM20). Moreover, the origin of the raw material used to manufacture the hydrolysates, as well as their hydrolysis level, seemed to be determining parameters for enhancing the morphological development of the intestine. The different specifications of the protein hydrolysates led to different 
Table 7 Functional enrichments related to the mixed hydrolysate diet (FM5 +5\% MH) as compared to the low FM diet (FM5)

\begin{tabular}{|c|c|c|c|}
\hline Pathway ID & Pathway description & Count in gene set & False discovery rate \\
\hline \multicolumn{4}{|c|}{ Biological Process (GO) } \\
\hline GO:0044281 & small molecule metabolic process & 47 & 1.29E-10 \\
\hline GO:0044255 & cellular lipid metabolic process & 27 & 1.35E-08 \\
\hline GO:0006629 & lipid metabolic process & 30 & 2.85E-08 \\
\hline GO:0019637 & organophosphate metabolic process & 25 & $1.72 \mathrm{E}-07$ \\
\hline GO:0044712 & single-organism catabolic process & 26 & $2.12 \mathrm{E}-07$ \\
\hline \multicolumn{4}{|c|}{ Molecular Function (GO) } \\
\hline GO:0003824 & catalytic activity & 71 & 4.72E-08 \\
\hline GO:0004305 & ethanolamine kinase activity & 4 & 4.71E-06 \\
\hline GO:0016491 & oxidoreductase activity & 20 & 2.75E-05 \\
\hline GO:0048037 & cofactor binding & 13 & 2.75E-05 \\
\hline GO:0050662 & coenzyme binding & 11 & 4.17E-05 \\
\hline \multicolumn{4}{|c|}{ Cellular Component (GO) } \\
\hline GO:0005829 & cytosol & 49 & $5.48 \mathrm{E}-06$ \\
\hline GO:0044444 & cytoplasmic part & 80 & 7.17E-06 \\
\hline GO:0031988 & membrane-bounded vesicle & 49 & 1.27E-05 \\
\hline GO:0070062 & extracellular exosome & 43 & 1.27E-05 \\
\hline GO:0044421 & extracellular region part & 50 & $2.76 \mathrm{E}-05$ \\
\hline \multicolumn{4}{|l|}{ KEGG Pathways } \\
\hline 1100 & Metabolic pathways & 32 & 4.73E-09 \\
\hline 100 & Steroid biosynthesis & 4 & 0.000973 \\
\hline 4975 & Fat digestion and absorption & 5 & 0.000973 \\
\hline 564 & Glycerophospholipid metabolism & 6 & 0.00308 \\
\hline 10 & Glycolysis/Gluconeogenesis & 4 & 0.0473 \\
\hline
\end{tabular}

responses of villi height, with a higher benefit from dietary $\mathrm{SH}$ than $\mathrm{TH}$, although $\mathrm{MH}$ performance lay in-between. However, it is still unclear whether this improved response was related to a dietary effect of $\mathrm{SH}$ on the intestinal mucosa due to i) the higher intake of free amino acids, or ii) a protective effect of the intestinal epithelium due to the presence of bioactive peptides in the hydrolysate, or iii) a modulation of the intestinal microbiota and/or of antimicrobial peptides. These hypotheses are not mutually exclusive. Although the mode of action of hydrolysates remains to be elucidated, this study confirms that they are beneficial for the fish intestine, as already observed in olive flounder [39]. It also confirms the potential of hydrolysates for replacing FM in aquafeeds for carnivorous species.

\section{Impact of hydrolysate inclusion in a low FM diet on intestine gene expression}

The intestine is a complex organ because many metabolic interactions take place inside it [49]. We analyzed the differentially expressed genes from the intestinal mucosa of European seabass fed different diets. Low FM
(FM5 diet) caused metabolic disturbances, and certain metabolic pathways were modulated in link with dietary inclusion of protein hydrolysates of different origins. Dietary FM reduction (FM5 diet) impaired several intestinal functions, i.e. nutrient transport, immune defense, gut morphogenesis (Fig. 2). These transcriptomic results are consistent with the lower performances recorded in sea bass fed the FM5 diet throughout the zootechnical trial.

The different transcriptomic data analyses evidenced a few discrepancies in sea bass responses depending on dietary hydrolysate origin (Tables 8 and 9). The comparative analysis of the two $\mathrm{SH}$ and $\mathrm{TH}$ protein hydrolysates confirmed that the sea bass intestinal transcriptomic response seemed to be closely related to the biochemical properties of each hydrolysate. Thus, based on GO term analysis, a higher proportion of genes (34.1\% vs. $12.7 \%)$ linked to hydrolases was differentially expressed in sea bass fed the $\mathrm{TH}$ diet as compared to the $\mathrm{SH}$ diet (Fig. 3). Interestingly, the regulated enzymes were not only implied in peptide/protein degradation, as expected from dietary protein hydrolysate inclusion, but also in carbohydrate degradation (malatase-gluco-amylase, aldolase B, 
Table 8 KEGG analysis of the top 5 pathways regulated by hydrolysate-supplemented diets as compared to the low FM diet (FM5)

\begin{tabular}{ll}
\hline TH diet & Nb. of regulated genes \\
01100 Metabolic pathways & 9 \\
04974 Protein digestion and absorption & 6 \\
03010 Ribosome & 3 \\
04972 Pancreatic secretion & 3 \\
01120 Microbial metabolism in diverse environments \\
SH diet & Nb. of regulated genes \\
01100 Metabolic pathways & 9 \\
04210 Apoptosis & 5 \\
04217 Necroptosis & 4 \\
05164 Influenza A & 4 \\
01110 Biosynthesis of secondary metabolites & 3 \\
MH diet & Nb. of regulated genes \\
01100 Metabolic pathways & 55 \\
01110 Biosynthesis of secondary metabolites & 28 \\
01130 Biosynthesis of antibiotics & 19 \\
00100 Steroid biosynthesis & 9 \\
05166 HTL-I infection & 9 \\
\hline
\end{tabular}

$T H$ tilapia hydrolysate, $\mathrm{SH}$ shrimp hydrolysate, $\mathrm{MH}$ mixed hydrolysate glucose-6-phosphatase), and probably stimulate starch degradation in the PBM fraction of diets (Table 4). These differences in gene expression of intestinal hydrolases might be explained by the different peptide compositions of tilapia and shrimp hydrolysates. $\mathrm{TH}$ is mainly composed of higher-molecular-weight peptides than $\mathrm{SH}$, and also exhibits higher peptide diversity than $\mathrm{SH}$ [40]. These higher-molecular-weight peptides could require additional hydrolysis by enterocyte enzymes, resulting in greater mRNA synthesis from genes related to protein digestion and absorption. On the contrary, GO terms of differentially expressed genes involved in the immune response (6.8\% vs. $23.6 \%$ ) and in the response to stimuli (34\% vs. $56.4 \%$ ) were less in sea bass fed the TH diet than in sea bass fed the $\mathrm{SH}$ diet (Fig. 3). In particular, the $\mathrm{SH}$ diet induced the expression of lectin-related genes (Table 6), which protect the intestinal mucosa from pathogenic bacterial invasion [81]. These findings support the immunostimulating effect of $\mathrm{SH}$. SH is mainly composed of low-molecular-weight peptides derived from the enzymatic cleavage of haemocyanin [37], which has immunostimulatory properties used in the treatment of cancers such as melanomas or in bioadjuvants for vaccines [82-84]. In addition, peptides derived from haemocyanin degradation are also known to exhibit other bioactive properties such as responses to stressors, pathogens (bacteria and parasites) and antibacterial agents [85]. Marine protein hydrolysates have been reported to have in

Table 9 Ingenuity Pathway Analysis: main pathways impacted by hydrolysate-supplemented diets

\begin{tabular}{|c|c|c|}
\hline TH diet versus FM5 diet & SH diet versus FM5 diet & MH diet versus FM5 diet \\
\hline $\begin{array}{l}\text { Top Canonical Pathways } \\
\text { (Name/p-value/Overlap) }\end{array}$ & $\begin{array}{l}\text { Top Canonical Pathways } \\
\text { (Name/p-value/Overlap) }\end{array}$ & $\begin{array}{l}\text { Top Canonical Pathways } \\
\text { (Name/p-value/Overlap) }\end{array}$ \\
\hline Glycolysis I/1.23E-03/8\% & $\begin{array}{l}\text { Role of Lipids/Lipid Rafts in the } \\
\text { Pathogenesis of Influenza/9.11E-04/9.1\% }\end{array}$ & $\begin{array}{l}\text { Superpathway of Cholesterol } \\
\text { Biosynthesis/2.13E-17/42.9\% }\end{array}$ \\
\hline Gluconeogenesis I/1.23E-03/8\% & Glutamine Biosynthesis 1/2.04E-03/100\% & $\begin{array}{l}\text { Cholesterol Biosynthesis 1/6.27E-16/ } \\
69.2 \%\end{array}$ \\
\hline Glutamine Biosynthesis I/2.08E-03/100\% & $\begin{array}{l}\text { Xanthine and Xanthosine Salvage/2.04E-03/ } \\
100 \%\end{array}$ & $\begin{array}{l}\text { Cholesterol Biosynthesis II (via 24.25- } \\
\text { dihydrolanosterol) / 6.27E-16/69.2\% }\end{array}$ \\
\hline FXR/RXR Activation/2.30E-03/2.4\% & $\begin{array}{l}\text { Type II Diabetes Mellitus Signalling/2.20E-03/ } \\
2.4 \%\end{array}$ & $\begin{array}{l}\text { Cholesterol Biosynthesis III } \\
\text { (via Desmosterol)/6.27E-/ } 69.2 \%\end{array}$ \\
\hline $\begin{array}{l}\text { IL-17A Signalling in Fibroblasts/2.41E-03/ } \\
5.7 \%\end{array}$ & $\begin{array}{l}\text { IL-17A Signalling in Fibroblasts/2.31E-03/ } \\
5.7 \%\end{array}$ & $\begin{array}{l}\text { Zymosterol Biosynthesis/1.48E-07/ } \\
66.7 \%\end{array}$ \\
\hline $\begin{array}{l}\text { Molecular and Cellular Functions } \\
\text { (Name/p-value/\#Molecules) }\end{array}$ & $\begin{array}{l}\text { Molecular and Cellular Functions } \\
\text { (Name/p-value/\#Molecules) }\end{array}$ & $\begin{array}{l}\text { Molecular and Cellular Functions } \\
\text { (Name/p-value/\#Molecules) }\end{array}$ \\
\hline Cell Morphology/2.27E-02 - 1.27E-05/9 & $\begin{array}{l}\text { Cell Death and Survival/1.73E-02 - 1.81E-05/ } \\
14\end{array}$ & $\begin{array}{l}\text { Lipid Metabolism/6.58E-03 - 2.66E- } \\
14 / 79\end{array}$ \\
\hline $\begin{array}{l}\text { Carbohydrate Metabolism/2.67E-02 - 6.33E- } \\
05 / 9\end{array}$ & $\begin{array}{l}\text { Cell-To-Cell Signalling and Interaction/1.62E- } \\
02-2.68 \mathrm{E}-05 / 10\end{array}$ & $\begin{array}{l}\text { Small Molecule Biochemistry/6.58E- } \\
03-2.66 \mathrm{E}-14 / 106\end{array}$ \\
\hline $\begin{array}{l}\text { Small Molecule Biochemistry/2.75E-02 - } \\
6.33 \mathrm{E}-05 / 20\end{array}$ & Cellular Development 1.72E-02 -/3.65E-05/15 & $\begin{array}{l}\text { Vitamin and Mineral Metabolism/ } \\
6.25 \mathrm{E}-03-1.96 \mathrm{E}-11 / 30\end{array}$ \\
\hline $\begin{array}{l}\text { Amino Acid Metabolism/2.67E-02 - 2.76E-04/ } \\
4\end{array}$ & $\begin{array}{l}\text { Cellular Function and Maintenance/1.73E-02 } \\
-3.65 \mathrm{E}-05 / 14\end{array}$ & $\begin{array}{l}\text { Molecular Transport/6.25E-03 - 3.02E- } \\
\text { 10/74 }\end{array}$ \\
\hline $\begin{array}{l}\text { Post-Translational Modification/1.24E-02 - } \\
2.76 \mathrm{E}-04 / 2\end{array}$ & $\begin{array}{l}\text { Cellular Growth and Proliferation/1.72E-02 - } \\
\text { 3.65E-05/12 }\end{array}$ & $\begin{array}{l}\text { Carbohydrate Metabolism/6.25E-03 - } \\
1.60 \text { E-08/43 }\end{array}$ \\
\hline
\end{tabular}

$T H$ tilapia hydrolysate, $S H$ shrimp hydrolysate, $M H$ mixed hydrolysate, $F M 5$ low fish meal diet 
vitro antibacterial [37, 40], antioxidant and/or immunomodulatory [86] functional properties. Our results seem to confirm immuno-stimulatory effects (interferon, histocompatibility antigen, lectin, pentraxin or serum complement system expression) at a transcriptomic level, as already observed in several carnivorous fish fed diets containing the same hydrolysates [32, 33, 38, 39, 87]. Moreover, hydrolysates down-regulated the expression of interferon-related genes. In fish, genes linked to interferon are expressed during viral infection [81], and in vertebrates, interferons are also involved in intestinal homeostasis after infection [88]. These transcriptomic results confirm that dietary hydrolysate supplementation has beneficial effects on the intestinal mucosa.

String analysis did not evidence any GO term or metabolic enrichment in diets containing hydrolysates of a specific origin (shrimp or tilapia). This result is surprising given the marked difference in growth responses between sea bass fed the FM5 diet and sea bass fed diets containing hydrolysates, as well as the positive response of intestine histological organization in sea bass fed the $\mathrm{SH}$ diet. For the SH diet, this may be due to the fact that sea bass fed the FM5 diet did not show any histological signs of severe enteritis or inflammation of the intestinal mucosa; besides, there was no change at a molecular level. Enteritis induces the regulation of a large number of genes (apoptosis, proinflammatory, oxidative stress, endocytosis, and cell migration) as already shown in a study on the replacement of FM by soybean meal in Atlantic salmon [48]. In our study, the physiological state of the sea bass may not have been sufficiently altered to induce a transcriptomic response taking into account our filtering treatment (absolute fold change $>1.4$ and $P$-adj $<0.2)$. Hence, the low number of regulated genes did not allow us to highlight any group of genes to explain the phenotypic differences observed between dietary treatments at a transcriptomic level.

On the contrary, in sea bass fed the diet containing the mixed hydrolysate ( $\mathrm{MH}$ diet), the much larger number of differentially regulated genes (270 as compared to the FM5 diet) made it possible to carry out an enrichment analysis with String both in GO terms and in metabolic pathways. The analysis showed that the lipid metabolism was strongly impacted, and acetyl-CoA appeared to play a central role in this process. Interestingly, the MH diet decreased cholesterol and long-chain fatty acid metabolism (Table 5). Genes involved in cholesterol and long-chain fatty acid metabolism were overexpressed in Atlantic salmon fed protein diets containing a high level of soybean meal [48]. On the contrary, these two genes families were down-regulated in European seabass fed the MH diet. Moreover, many genes coding for apolipoprotein, which is involved in lipid transport, were down-regulated in sea bass fed with the mixed hydrolysate. These results provide evidence for a significant effect of the mixed hydrolysate diet on lipid metabolism at the transcriptomic level. Such an effect would deserve to be deeply investigated to understand the phenotypic consequences (lipid utilization and storage) of such gene responses to dietary protein hydrolysate. It is worth noting that modulation of lipid metabolism by dietary protein hydrolysates has already been observed in turbot and mice, with a beneficial effect on the reduction of visceral lipid accumulation [35, 89-91].

The MH diet also promoted European seabass health status by regulating the same immuno-stimulatory related genes as the $\mathrm{TH}$ and $\mathrm{SH}$ diets, but also by specifically modulating the expression of specific genes, such as $\mathrm{H}^{-2}$ class I and class II histocompatibility antigen genes, which were over-expressed (Table 6). Moreover, the genes involved in the response to cellular damage (glutathione peroxidase, DNA damage repair) were under-expressed, which suggests an improvement of intestinal health and condition. Król et al. demonstrated that deregulation of the intestine (enteritis) induced the overexpression of genes linked to the oxidative defenses of epithelial cells [48]. A possible explanation for this larger number of differentially regulated genes may be that the combined hydrolysates provided a wider variety of functional peptides, an important characteristic linked to the performance of dietary protein hydrolysates [34].

Nevertheless, a focus could be performed further by qPCR in order to target the major actors of the main metabolic pathways highlighted by this study.

\section{Restoring the intestinal transcriptomic profile of the high FM diet with a low FM diet supplemented with protein hydrolysates}

Hydrolysate diets induced a similar pattern of gene expression as the control diet (FM20), regardless of the included hydrolysate. Compared to the FM20 diet, the number of differentially regulated genes was very low for all hydrolysate diets, with 6,8 , and 6 genes for the $\mathrm{TH}$, $\mathrm{SH}$, and $\mathrm{MH}$ diets, respectively (Additional file 3). Once again, regulated genes were specific to hydrolysate origin, so that no gene was regulated by all three $\mathrm{TH}, \mathrm{SH}$ and $\mathrm{MH}$ diets as compared to the FM20 group. Another mechanism involved in the differences in gene regulation between hydrolysate diets may be related to the glycosylation types in the resulting peptide fragments. The method used to generate these hydrolysates may also influence the degree of conservation of the glycosidic residues. Immune stimulation was more prominent in sea bass fed with $\mathrm{SH}$; in parallel, glycosylation patterns conserved among plants and invertebrates have been found to be immunogenic in vertebrates [92]. Further work in the area of protein glycosylation may also 
be profitable and provide insights into this hypothesis. Although it is difficult to conclude about the relationship between regulated genes and the functional benefits of the $\mathrm{TH}$ diet, our results show that the $\mathrm{SH}$ diet down-regulated members of the GTPase IMAP family (members 6, 7 and 8) related to immunity. This highlights again the immunomodulatory effect of SH. Regarding the $\mathrm{MH}$ diet, Acyl-CoA desaturase and UDP-glucose 6-dehydrogenase were respectively overand under-expressed as compared to the FM20 diet. Therefore the lipid and carbohydrate pathways were modulated by this dietary treatment. Achieving the performance of a diet rich in FM during grow-out is a key point when dealing with low FM diets and alternative ingredients. In this study, the incorporation of 5\% of hydrolysate compensated for the metabolic disturbances associated with the replacement of $15 \%$ of FM by a mixture of plant proteins, as observed in European seabass fed the FM5 diet. The intestinal transcriptomic response confirmed the results obtained at the zootechnical and gut histological levels, i.e. protein hydrolysates of aquaculture origin are valuable candidates to support FM replacement without deteriorating the zootechnical and functional performances of aquafeeds.

\section{Conclusion}

Within the global context of FM replacement in aquaculture feed formulation, evaluating the performance of new raw materials has become a crucial economic stake for aquafeed manufacturers. Although assessing the zootechnical performances of new formulations remains indispensable, the development of new protocols and tools for molecular and biochemical investigations can provide a more comprehensive view of the response of animals to novel diets. We combined zootechnical and transcriptomic approaches to evaluate the performances of protein hydrolysates as surrogates of dietary FM in European seabass. The reduction of the dietary FM level from 20 to $5 \%$ significantly impaired growth performances, intestinal histological organization, and induced significant changes in the transcriptomic profile of the intestine. By incorporating protein hydrolysate into the low FM diet (FM5) restored European seabass performances to a similar high level to those recorded with the high FM diet (FM20). In addition, this study demonstrates that the raw material used to manufacture protein hydrolysate is an important determinant in the transcriptomic response of fish.

Although the hydrolysates promoted the same zootechnical performances, the transcriptomic response of the intestine showed that genes and metabolic pathways were modulated in a hydrolysate-dependent manner. Moreover, including a combination of tilapia and shrimp hydrolysates into European seabass feed regulated a higher number of genes than the independent hydrolysates. It would be interesting to assess hydrolysate performances in fish grown under more challenging conditions (high density, low oxygen, low/ high temperature,...) to check how these differences in transcriptomic profiles are translated into phenotypic responses. These results offer an interesting scenario for the formulation of new high-performance feeds with a low level of FM inclusion. The analysis of the transcriptomic responses of liver and kidney sampled in the present study will allow us to complete this work and to better understand how metabolic pathways are modulated by the replacement of FM by protein hydrolysates in European seabass.

\section{Additional files}

Additional file 1: Diet formulation and proximal composition. FM5, 5\% fish meal diet; FM20, 20\% fish meal diet; TH, tilapia hydrolysate diet; SH, shrimp hydrolysate diet; $\mathrm{MH}$, mixed hydrolysate diet. (XLSX 10 kb)

Additional file 2: Global list and fold changes of differentially expressed genes versus FM5. Values correspond to fold changes between diets and the low fish meal control diet. Positive values indicate upregulation, and negative values down regulation. FM5, 5\% fish meal diet; FM20, 20\% fish meal diet; $\mathrm{TH}$, tilapia hydrolysate diet; $\mathrm{SH}$, shrimp hydrolysate diet; $\mathrm{MH}$, mixed hydrolysate diet. Values with "*" correspond to fold change means of isoforms. If isoforms were at the same time up and down regulated each values appear. (XLSX $37 \mathrm{~kb}$ )

Additional file 3: Global list and fold changes of differentially expressed genes versus FM20. Values correspond to fold changes between hydrolysate diets and the high fish meal control diet. Positive values indicate upregulation, and negative values down regulation. (XLSX $10 \mathrm{~kb}$ )

Additional file 4: Relationship between regulated genes by hydrolysate diets. Differentially expressed gene compared to low fish meal diet have been tested against Homo sapiens background. Only connected genes are presented. A. relation between the regulated genes by shrimp hydrolysate diet. B. relation between the regulated genes by tilapia hydrolysate diet. C. relation between the regulated genes by mixed hydrolysate diet. (TIF $2612 \mathrm{~kb}$ )

Additional file 5: KEGG analysis: list of genes differentially expressed by hydrolysate and high fish meal diets compared to low fish meal diet. (XLSX $63 \mathrm{~kb}$ )

Additional file 6: IPA analysis: list of main pathways impacted by hydrolysate and high fish meal diets compared to low fish meal diet. (XLSX 57 kb)

\section{Acknowledgments}

The authors would like to thank Dominique Vaur, Nicolas Goardon and Angelina Legros for the technical assistance on the Miseq sequencing experiment at the SéSAME platform.

\section{Funding}

A. Leduc was supported by the Association Nationale de la Recherche et de la Technologie (grant number 2014/1274), and by DIANA AQUA (Symrise group). E. Gisbert and K. Blyth Andree were partially supported by the MINECO (Spanish Government, project reference AGL2014-51839-C6-5-R).

\section{Availability of data and materials}

The datasets supporting the conclusions of this article are included within the article (and its additional files). The raw data generated and/or analyzed during the current study is not publicly available due to the data mining still in progress. Nevertheless, some data could be available from the corresponding author on reasonable request. 


\section{Authors' contributions}

CZG, VF and JH conceived and designed the study and corrected the manuscrit. MR, EG and KA performed feeding trial and sampling. EC and GLC performed bioinformatics analysis. $\mathrm{HC}$ and ALS performed IPA analysis. AL performed RNAseq banking, Go term, String and KEGG analyzes, interpreted results and wrote the manuscript. All authors discussed, commented on the manuscript and approved the final manuscript.

\section{Ethics approval}

All experimental procedures involving sea bass were conducted in compliance with the experimental research protocol approved by the Committee of Ethics and Animal Experimentation of the IRTA, the Departament Agricultura, Ramaderia, Pesca, Alimentació i Medi Natural (permit number 7962) and in accordance with the Guidelines of the European Union Council (86/609/EU) for the use of laboratory animals.

\section{Competing interests}

The authors declare that they have no competing interests.

\section{Publisher's Note}

Springer Nature remains neutral with regard to jurisdictional claims in published maps and institutional affiliations.

\section{Author details}

${ }^{1}$ Normandie University, UNICAEN, Sorbonne Universités, MNHN, UPMC Univ Paris 06, UA, CNRS, IRD, Biologie des Organismes et Ecosystèmes Aquatiques (BOREA), Université de Caen Normandie, Caen 14032, France. ${ }^{2}$ UPMC, CNRS, FR2424, ABiMS, Station Biologique, Roscoff, France. ${ }^{3}$ Normandie University, UNIROUEN, INSERM, U1239, Laboratoire Différenciation et Communication Neuronale et Neuroendocrine, Institut de Recherche et d'Innovation Biomédicale de Normandie, Rouen, France. ${ }^{4}$ Aquativ (DianaAqua, Symrise Group), Elven, France. ${ }^{5}$ Institute of Agriculture and Food Research and Technology (IRTA), Sant Carles de la Ràpita, Spain.

\section{Received: 4 January 2018 Accepted: 10 May 2018}

\section{Published online: 24 May 2018}

\section{References}

1. FAO. FAO Global Aquaculture Production statistics database updated to Summary information. Food Agric Oraganization United Nations. 2013;2015:2013. Available: http://www.fao.org/3/a-i4899e.pdf

2. World Bank. Fish to 2030: Prospects for fisheries and aquaculture. Agric Environ Serv Discuss Pap. 2013;3: 102. doi:83177-GLB.

3. Hardy RW. Utilization of plant proteins in fish diets: Effects of global demand and supplies of fishmeal. Aquaculture Research. 2010:770-6. https://doi.org/10.1111/j.1365-2109.2009.02349.x.

4. Duarte $C M$, Holmer M, Olsen Y, Soto D, Marbà N, Guiu J, et al. Will the oceans help feed humanity? Bioscience. 2009;59:967-76. https://doi.org/10. 1525/bio.2009.59.11.8.

5. Robaina L, Izquierdo MS, Moyano FJ, Socorro J, Vergara JM, Montero D, et al. Soybean and lupin seed meals as protein sources in diets for gilthead seabream (Sparus aurata): nutritional and histological implications. Aquaculture. 1995;130:219-33. https://doi.org/10.1016/0044-8486(94)00225-D

6. Kaushik SJ, Covès D, Dutto G, Blanc D. Almost total replacement of fish meal by plant protein sources in the diet of a marine teleost, the European seabass, Dicentrarchus labrax. Aquaculture. 2004;230:391-404. https://doi.org/10.1016/S0044-8486(03)00422-8.

7. Salze G, McLean E, Battle PR, Schwarz MH, Craig SR. Use of soy protein concentrate and novel ingredients in the total elimination of fish meal and fish oil in diets for juvenile cobia, Rachycentron canadum. Aquaculture.. Elsevier B.V.; 2010;298: 294-299 doi:https://doi.org/10.1016/j.aquaculture. 2009.11.003

8. Moxley JD, Rossi W, Buentello A, Pohlenz C, Gatlin DM, Tomasso JR. Replacement of fish meal with plant feedstuffs in the diet of red drum, Sciaenops ocellatus: effects on production characteristics and tolerance to aquaculture-related stressors. J World Aquac Soc. 2014;45:192-8. https://doi.org/10.1111/jwas.12106.

9. Aksnes A, Hope B, Jönsson E, Björnsson BT, Albrektsen S. Size-fractionated fish hydrolysate as feed ingredient for rainbow trout (Oncorhynchus mykiss) fed high plant protein diets. I: growth, growth regulation and feed utilization. Aquaculture. 2006;261:305-17. https://doi.org/10.1016/j. aquaculture.2006.07.025

10. Hernández MD, Martínez FJ, Jover M, García B. Effects of partial replacement of fish meal by soybean meal in sharpsnout seabream (Diplodus puntazzo) diet. Aquaculture. 2007;263:159-67. https://doi.org/10.1016/j.aquaculture. 2006.07.040.

11. Médale F, Kaushik S. Les sources protéiques dans les aliments pour les poissons d'élevage. Cah Agric. 2009;18:103-11. https://doi.org/10.1684/agr. 2009.0279.

12. Francis G, Makkar HPS, Becker K. Antinutritional factors present in plantderived alternate fish feed ingredients and their effects in fish. Aquaculture. 2001:197-227. https://doi.org/10.1016/S0044-8486(01)00526-9.

13. Krogdahl A, Hemre Gl, Mommsen TP. Carbohydrates in fish nutrition: Digestion and absorption in postlarval stages. Aquaculture Nutrition. 2005:103-22. https://doi.org/10.1111/j.1365-2095.2004.00327.x.

14. Baeverfjord G, Krogdahl Å. Development and regression of soybean meal induced enteritis in Atlantic salmon, Salmo salar L., distal intestine: a comparison with the intestines of fasted fish. J Fish Dis. 1996;19:375-87. https://doi.org/10.1046/j.1365-2761.1996.d01-92.x.

15. Urán PA, Gonçalves AA, Taverne-Thiele JJ, Schrama JW, Verreth JAJ, Rombout JHWM. Soybean meal induces intestinal inflammation in common carp (Cyprinus carpio L.). Fish Shellfish Immunol. 2008;25:751-60. https://doi. org/10.1016/j.fsi.2008.02.013.

16. Bakke-McKellep AM, McL Press C, Baeverfjord G, Krogdahl A, Landsverk T. Changes in immune and enzyme histochemical phenotypes of cells in the intestinal mucosa of Atlantic salmon, Salmo salar L., with soybean mealinduced enteritis. J Fish Dis. 2000;23:115-27. https://doi.org/10.1046/j.1365$2761.2000 .00218 x$

17. Sitjà-Bobadilla A, Peña-Llopis S, Gómez-Requeni P, Médale F, Kaushik S, Pérez-Sánchez J. Effect of fish meal replacement by plant protein sources on non-specific defence mechanisms and oxidative stress in gilthead sea bream (Sparus aurata). Aquaculture. 2005;249:387-400. https://doi.org/10. 1016/j.aquaculture.2005.03.031

18. Kousoulaki K, Sether BS, Albrektsen S, Noble C. Review on European sea bass (Dicentrarchus labrax, Linnaeus, 1758) nutrition and feed management: a practical guide for optimizing feed formulation and farming protocols. Aquac Nutr. 2015;21:129-51. https://doi.org/10.1111/anu.12233.

19. Hardy RW, Tacon AGJ. Fishmeal: historical uses, production trends and future outlook for supplies. Responsible Marine Aquaculture. Wallingford: CABl; 2002. pp. 311-325. doi:https://doi.org/10.1079/9780851996042.0311.

20. Naylor RL, Hardy RW, Bureau DP, Chiu A, Elliott M, Farrell AP, et al. Feeding aquaculture in an era of finite resources. Proc Natl Acad Sci U S A. 2009;106:15103-10. https://doi.org/10.1073/pnas.0905235106.

21. Hardy RW, Sealey WM, Gatlin DM. Fisheries By-Catch and By-Product Meals as Protein Sources For Rainbow Trout Oncorhynchus mykiss. J World Aquac Soc. 2005;3:393-400. https://doi.org/10.1111/j.1749-7345. 2005.tb00343.x

22. Hsu KC. Purification of antioxidative peptides prepared from enzymatic hydrolysates of tuna dark muscle by-product. Food Chem. 2010;122:42-8. https://doi.org/10.1016/j.foodchem.2010.02.013.

23. Lee KJ, Powell MS, Barrows FT, Smiley S, Bechtel P, Hardy RW. Evaluation of supplemental fish bone meal made from Alaska seafood processing byproducts and dicalcium phosphate in plant protein based diets for rainbow trout (Oncorhynchus mykiss). Aquaculture. 2010;302:248-55. https://doi.org/10.1016/j.aquaculture.2010.02.034.

24. Chalamaiah M, Dinesh Kumar B, Hemalatha R, Jyothirmayi T. Fish protein hydrolysates: proximate composition, amino acid composition, antioxidant activities and applications: a review. Food Chem Elsevier Ltd. 2012;135: 3020-38. https://doi.org/10.1016/j.foodchem.2012.06.100.

25. Se-Know K. Seafood processing by-products [internet]. Seafoods: chemistry, processing technology and quality. Springer US: Boston; 2014. https://doi.org/10.1007/978-1-4614-9590-1.

26. Gildberg A. Enzymic processing of marine raw materials. Process Biochemistry. 1994:1-15. https://doi.org/10.1016/0032-9592(94)80030-8.

27. Kristinsson $\mathrm{HG}$, Rasco BA. Fish protein Hydrolysates: production, biochemical, and functional properties [internet]. Crit Rev Food Sci Nutr. 2000; https://doi.org/10.1080/10408690091189266.

28. Refstie S, Olli JJ, Standal H. Feed intake, growth, and protein utilisation by post-smolt Atlantic salmon (Salmo salar) in response to graded levels of fish protein hydrolysate in the diet. Aquaculture 2004:239:331-49. https://doi. org/10.1016/j.aquaculture.2004.06.015. 
29. Cahu CL, Zambonino Infante JL, Quazuguel P, Le Gall MM. Protein hydrolysate vs. fish meal in compound diets for 10-day old sea bass Dicentrarchus labrax larvae. Aquaculture. 1999;171:109-19. https://doi.org/ 10.1016/S0044-8486(98)00428-1.

30. Choi YJ, Hur S, Choi BD, Konno K, Park JW. Enzymatic hydrolysis of recovered protein from frozen small croaker and functional properties of its hydrolysates. J Food Sci. 2009;74 https://doi.org/10.1111/j.1750-3841.2008. 00988.x.

31. Gisbert E, Skalli A, Fernández I, Kotzamanis Y, Zambonino-Infante JL, Fabregat R. Protein hydrolysates from yeast and pig blood as alternative raw materials in microdiets for gilthead sea bream (Sparus aurata) larvae. Aquaculture. Elsevier B.V.; 2012;338-341: 96-104. doi:https://doi.org/10.1016/ j.aquaculture.2012.01.007

32. Kotzamanis YP, Gisbert E, Gatesoupe FJ, Zambonino Infante J, Cahu C. Effects of different dietary levels of fish protein hydrolysates on growth, digestive enzymes, gut microbiota, and resistance to Vibrio anguillarum in European sea bass (Dicentrarchus labrax) larvae. Comp Biochem Physiol - A Mol Integr Physiol. 2007;147:205-14. https://doi.org/10.1016/j.cbpa.2006.12.037.

33. Tang HG, Wu TX, Zhao ZY, Pan XD. Effects of fish protein hydrolysate on growth performance and humoral immune response in large yellow croaker (Pseudosciaena crocea R.). J Zhejiang Univ Sci B. 2008;9:684-90. https://doi.org/10.1631/jzus.B0820088.

34. Espe M, Sveier $H$, Hogoy I, Lied E. Nutrient absorption and growth of Atlantic salmon (Salmo salar L.) fed fish protein concentrate. Aquaculture. 1999:174, 119-37. https://doi.org/10.1016/S0044-8486(98)00502-X.

35. Liaset B, Lied E, Espe M. Enzymatic hydrolysis of by-products from the fishfilleting industry; chemical characterisation and nutritional evaluation. J Sci Food Agric. 2000;80:581-9. https://doi.org/10.1002/(SICI)10970010(200004)80:5<581::AID-JSFA578>3.0.CO;2-1.

36. Plascencia-Jatomea M, Olvera-Novoa MA, Arredondo-Figueroa JL, Hall GM, Shirai K. Feasibility of fishmeal replacement by shrimp head silage protein hydrolysate in Nile tilapia (Oreochromis niloticus L) diets. J Sci Food Agric. John Wiley \& Sons, Ltd.; 2002;82: 753-759. doi:https://doi.org/10.1002/jsfa. 1092

37. Robert M, Zatylny-Gaudin C, Fournier V, Corre E, Le Corguillé G, Bernay B, et al. Transcriptomic and peptidomic analysis of protein hydrolysates from the white shrimp (L. vannamei). J Biotechnol. 2014;186:30-7. https://doi.org/ 10.1016/j.jbiotec.2014.06.020.

38. Khosravi S, Rahimnejad S, Herault M, Fournier V, Lee C-R, Dio Bui HT, et al. Effects of protein hydrolysates supplementation in low fish meal diets on growth performance, innate immunity and disease resistance of red sea bream Pagrus major. Fish Shellfish Immunol. 2015;45:858-68. https://doi.org/ 10.1016/j.fsi.2015.05.039.

39. Khosravi S, Bui HTD, Herault M, Fournier V, Kim K-D, Lee B-J, et al. Supplementation of protein Hydrolysates to a low-fishmeal diet improves growth and health status of juvenile olive flounder, Paralichthys olivaceus. J World Aquac Soc. 2017; https://doi.org/10.1111/jwas.12436.

40. Robert M, Zatylny-Gaudin C, Fournier V, Corre E, Le Corguillé G, Bernay B, et al. Molecular characterization of peptide fractions of a Tilapia (Oreochromis niloticus) by-product hydrolysate and in vitro evaluation of antibacterial activity. Process Biochem. 2015;50:487-92. https://doi.org/10.1016/j.procbio. 2014.12.022

41. Khosravi S, Bui HTD, Rahimnejad S, Herault M, Fournier V, Jeong JB, et al. Effect of dietary hydrolysate supplementation on growth performance, non-specific immune response and disease resistance of olive flounder (Paralichthys olivaceus ) challenged with Edwardsiella tarda. Aquac Nutr. 2015;21:321-31. https://doi.org/10.1111/anu.12157.

42. Léauté J-P. Approche du regime alimentaire des juveniles de bars et de limandes en baie de Somme. Rev des Trav I'Institut des Pêches Marit. 1984;48:55-63.

43. Kaushik SJ. European sea bass, Dicentrarchus labrax. Nutr Requir Feed finfish Aquac. 2002:28-39. https://doi.org/10.1079/9780851995199.0028.

44. Hardy RW. Farmed fish diet requirements for the next decade and implication for global availability of nutrients. In: Lim C, Webster CW, Lee E CS, editors. Alternative protein sources in aquaculture diets. New York: TheHaworth press; 2008. p. 1-16.

45. Robert M. Développement d'hydrolysats pour l'alimentation des animaux d'aquaculture : caractérisation moléculaire et fonctionnelle. Université de Caen Basse-Normandie. 2014;

46. Calduch-Giner JA, Sitjà-Bobadilla A, Pérez-Sánchez J. Gene expression profiling reveals functional specialization along the intestinal tract of a carnivorous teleostean fish (Dicentrarchus labrax). Front Physiol. 2016;7:1-17. https://doi.org/10.3389/fphys.2016.00359.

47. Gisbert E, Andree KB, Quintela JC, Calduch-Giner JA, Ipharraguerre IR, PérezSánchez J. Olive oil bioactive compounds increase body weight, and improve gut health and integrity in gilthead sea bream (Sparus aurata). Br J Nutr. 2017;117:351-63. https://doi.org/10.1017/S0007114517000228.

48. Król E, Douglas A, Tocher DR, Crampton VO, Speakman JR, Secombes CJ, et al. Differential responses of the gut transcriptome to plant protein diets in farmed Atlantic salmon. BMC Genomics. 2016;17:156. https://doi.org/10. 1186/s12864-016-2473-0

49. Martin SAM, Dehler CE, Król E. Transcriptomic responses in the fish intestine. Dev Comp Immunol. 2016;64:103-17. https://doi.org/10.1016/j.dci.2016.03. 014.

50. Zhang Y, Li Y, Liang X, Cao X, Huang L, Yan J, et al. Hepatic transcriptome analysis and identification of differentially expressed genes response to dietary oxidized fish oil in loach Misgurnus anguillicaudatus. PLoS One. 2017:12:1-17. https://doi.org/10.1371/journal.pone.0172386.

51. Wilson RP. Amino acids and protein. In: Hardy JH and R, editor. Fish nutrition, 3rd ed. San Diego: academic press; 2002. p. 143-79.

52. Pearse AGE. Carbohydrates and mucosubstances. Histochem Theor Appl. Analytical technology Churchill Livingstone. Edinburgh. 1985;2:675-753.

53. Escaffre A-M, Kaushik S, Mambrini M. Morphometric evaluation of changes in the digestive tract of rainbow trout (Oncorhynchus mykiss) due to fish meal replacement with soy protein concentrate. Aquaculture. 2007;273:127-38. https://doi.org/10.1016/j.aquaculture.2007.09.028.

54. Cornet V, Henry J, Corre E, Le Corguille G, Zanuttini B, Zatylny-Gaudin C. Dual role of the cuttlefish salivary proteome in defense and predation. J Proteomics Elsevier BV. 2014;108:209-22. https://doi.org/10.1016/j.jprot.2014. 05.019.

55. Bolger AM, Lohse M, Usadel B. Trimmomatic: a flexible trimmer for Illumina sequence data. Bioinformatics. 2014;30:2114-20. https://doi.org/10.1093/ bioinformatics/btu170.

56. Grabherr MG, Haas BJ, Levin MYJZ, Thompson DA, Amit I, Adiconis X, Fan L, Raychowdhury R, Zeng Q, Chen Z, Mauceli E, Hacohen N, Gnirke A, Rhind N, di Palma F, Bruce W, Friedman N, AR. Trinity: reconstructing a full-length transcriptome without a genome from RNA-Seq data. Nat Biotechnol. 2013;29:644-52. https://doi.org/10.1038/nbt.1883.Trinity.

57. Langmead B, Trapnell C, Pop M, Salzberg SL. Ultrafast and memory-efficient alignment of short DNA sequences to the human genome. Genome Biol. 2009;10:R25. https://doi.org/10.1186/gb-2009-10-3-r25.

58. Li B, Dewey CN. RSEM: accurate transcript quantification from RNA-Seq data with or without a reference genome. BMC Bioinformatics. 2011;12:323. https://doi.org/10.1186/1471-2105-12-323.

59. Conesa A, Götz S, García-Gómez JM, Terol J, Talón M, Robles M. Blast2GO: a universal annotation and visualization tool in functional genomics research. Application note. Bioinformatics. 2005;21:3674-6. https://doi.org/10.1093/ bioinformatics/bti610.

60. Haas BJ, Papanicolaou A, Yassour M, Grabherr M, Blood PD, Bowden J, et al. De novo transcript sequence reconstruction from RNA-seq using the Trinity platform for reference generation and analysis. Nat Protoc. 2013:8:1494-512. https://doi.org/10.1038/nprot.2013.084.

61. Petersen TN, Brunak S, von Heijne G, Nielsen H. SignalP 4.0: discriminating signal peptides from transmembrane regions. Nat Methods. 2011;8:785-6. https://doi.org/10.1038/nmeth.1701.

62. Krogh A, Larsson B, von Heijne G, Sonnhammer EL. Predicting transmembrane protein topology with a hidden markov model: application to complete genomes. J Mol Biol. 2001;305:567-80. https://doi.org/10.1006/ jmbi.2000.4315.

63. Finn RD, Bateman A, Clements J, Coggill P, Eberhardt RY, Eddy SR, et al. Pfam: the protein families database. Nucleic Acids Res. 2014; https://doi.org/ 10.1093/nar/gkt1223.

64. R Development Core Team. R: A language and environment for statistical computing. R Foundation for Statistical Computing, Vienna, Austria. URL http://www.R-project.org/. R Foundation for Statistical Computing, Vienna, Austria. 2013.

65. Love Ml, Huber W, Anders S. Moderated estimation of fold change and dispersion for RNA-seq data with DESeq2. Genome Biol. 2014;15:550. https://doi.org/10.1186/s13059-014-0550-8.

66. Ye J, Fang L, Zheng H, Zhang Y, Chen J, Zhang Z, et al. WEGO: a web tool for plotting GO annotations. Nucleic Acids Res. 2006;34 https://doi.org/10. 1093/nar/gkl031. 
67. Santigosa E, García-Meilán I, Valentin JM, Pérez-Sánchez J, Médale F, Kaushik $\mathrm{S}$, et al. Modifications of intestinal nutrient absorption in response to dietary fish meal replacement by plant protein sources in sea bream (Sparus aurata) and rainbow trout (Onchorynchus mykiss). Aquaculture. 2011;317:146-54. https://doi.org/10.1016/j.aquaculture.2011.04.026.

68. Estévez A, Treviño L, Kotzamanis Y, Karacostas I, Tort L, Gisbert E. Effects of different levels of plant proteins on the ongrowing of meagre (Argyrosomus regius) juveniles at low temperatures. Aquac Nutr. 2011;17 https://doi.org/10.1111/j.1365-2095.2010.00798.x.

69. Ribeiro L, Moura J, Santos M, Colen R, Rodrigues V, Bandarra N, et al. Effect of vegetable based diets on growth, intestinal morphology, activity of intestinal enzymes and haematological stress indicators in meagre (Argyrosomus regius). Aquaculture. Elsevier BV. 2014;447:116-28. https://doi. org/10.1016/j.aquaculture.2014.12.017.

70. De Santis C, Ruohonen K, Tocher DR, SAM M, Krol E, Secombes CJ, et al. Atlantic salmon (Salmo salar) parr as a model to predict the optimum inclusion of air classified faba bean protein concentrate in feeds for seawater salmon. Aquaculture. 2015;444:70-8. https://doi.org/10.1016/j. aquaculture.2015.03.024.

71. Penn MH, Bendiksen EA, Campbell P, Krogdahl AS. High level of dietary pea protein concentrate induces enteropathy in Atlantic salmon (Salmo salar L.). Aquaculture. 2011;310:267-73. https://doi.org/10.1016/j.aquaculture.2010.10.040.

72. Krogdahl $\AA$, Bakke-McKellep AM, Baeverfjord G. Effects of graded levels of standard soybean meal on intestinal structure, mucosal enzyme activities, and pancreatic response in Atlantic salmon (Salmo solar L.). Aquac Nutr. 2003;9:361-71. https://doi.org/10.1046/j.1365-2095.2003.00264.X.

73. Knudsen D, Jutfelt F, Sundh H, Sundell K, Koppe W, Frøkiær H. Dietary soya saponins increase gut permeability and play a key role in the onset of soyabean-induced enteritis in Atlantic salmon ( Salmo salar L.). Br J Nutr. 2008;100:120-9. https://doi.org/10.1017/S0007114507886338.

74. Zhang JX, Guo LY, Feng L, Jiang WD, Kuang SY, Liu Y, et al. Soybean $\beta$ Conglycinin induces inflammation and oxidation and causes dysfunction of intestinal digestion and absorption in fish. PLoS One. 2013;8:1-12. https://doi.org/10.1371/journal.pone.0058115.

75. Caspary WF. Physiology and pathophysiology of intestinal absorption. Am J Clin Nutr. 1992;55:299S-308S.

76. McGuckin MA, Lindén SK, Sutton P, Florin TH. Mucin dynamics and enteric pathogens. Nat Rev Microbiol Nature Publishing Group. 2011;9:265-78. https://doi.org/10.1038/nrmicro2538.

77. Li H, Limenitakis JP, Fuhrer T, Geuking MB, Lawson M a, Wyss M, et al. The outer mucus layer hosts a distinct intestinal microbial niche. Nat Commun 2015;6: 8292. doi:https://doi.org/10.1038/ncomms9292.

78. Heikkinen J, Vielma J, Kemiläinen O, Tiirola M, Eskelinen P, Kiuru T, et al. Effects of soybean meal based diet on growth performance, gut histopathology and intestinal microbiota of juvenile rainbow trout (Oncorhynchus mykiss). Aquaculture. 2006;261:259-68. https://doi.org/10 1016/j.aquaculture.2006.07.012

79. Bakke-McKellep AM, Penn MH, Salas PM, Refstie S, Sperstad S, Landsverk T, et al. Effects of dietary soyabean meal, inulin and oxytetracycline on intestinal microbiota and epithelial cell stress, apoptosis and proliferation in the teleost Atlantic salmon (Salmo salar L.). Br J Nutr. 2007;97:699-713. https://doi.org/10.1017/S0007114507381397.

80. Krogdahl Å, Bakke-McKellep a M, Røed KH, Baeverfjord G. Feeding Atlantic salmon Salmo salar L. soybean products: effects on disease resistance (furunculosis), and lysozyme and lgM levels in the intestinal mucosa. Aquac Nutr. 2000;6:77-84. https://doi.org/10.1046/j.1365-2095.2000.00129.x.

81. Ellis AE. Innate host defense mechanisms of fish against viruses and bacteria. Dev Comp Immunol. 2001;25:827-39. https://doi.org/10.1016/ S0145-305X(01)00038-6.

82. Talaei Zanjani N, Miranda-saksena M, Valtchev P, Diefenbach RJ, Hueston L, Diefenbach $E$, et al. Abalone Hemocyanin blocks the entry of herpes simplex virus 1 into Cells : a potential new antiviral strategy. Antimicrob Agents Chemother. 2016;60:1003-12. https://doi.org/10.1128/AAC.01738-15. Address.

83. Arancibia S, Espinoza C, Salazar F, Del Campo M, Tampe R, Zhong TY, et al. A novel immunomodulatory hemocyanin from the limpet Fissurella latimarginata promotes potent anti-tumor activity in melanoma. PLoS One. 2014;9 https://doi.org/10.1371/journal.pone.0087240.

84. Moltedo B, Faunes F, Haussmann D, De loannes P, De loannes AE, Puente J, et al. Immunotherapeutic effect of Concholepas Hemocyanin in the murine bladder Cancer model: evidence for conserved antitumor properties among Hemocyanins. J Urol. 2006;176:2690-5. https://doi.org/ 10.1016/j.juro.2006.07.136.

85. Coates CJ, Decker H. Immunological properties of oxygen-transport proteins: hemoglobin, hemocyanin and hemerythrin. Cell Mol Life Sci Springer. 2017;74:293-317. https://doi.org/10.1007/s00018-016-2326-7.

86. Kim SK, Mendis E. Bioactive compounds from marine processing byproducts - a review. Food Res Int. 2006:383-93. https://doi.org/10.1016/j.foodres.2005. 10.010 .

87. Bui HTD, Khosravi S, Fournier V, Herault M, Lee KJ. Growth performance, feed utilization, innate immunity, digestibility and disease resistance of juvenile red seabream (Pagrus major) fed diets supplemented with protein hydrolysates. Aquaculture. 2014;418-419:11-6. https://doi.org/10.1016/j. aquaculture.2013.09.046

88. Nava P, Koch S, Laukoetter MG, Lee WY, Kolegraff K, Capaldo CT, et al. Interferon- $\gamma$ regulates intestinal epithelial homeostasis through converging $\beta$-catenin signaling pathways. Immunity. 2011;32:392-402. https://doi.org/ 10.1016/j.immuni.2010.03.001.Interferon-

89. Bjørndal B, Berge C, Ramsvik MS, Svardal A, Bohov P, Skorve J, et al. A fish protein hydrolysate alters fatty acid composition in liver and adipose tissue and increases plasma carnitine levels in a mouse model of chronic inflammation. Lipids Health Dis. 2013;12:143. https://doi.org/10.1186/1476511X-12-143.

90. Liaset B, Madsen L, Hao Q, Criales G, Mellgren G, Marschall HU, et al. Fish protein hydrolysate elevates plasma bile acids and reduces visceral adipose tissue mass in rats. Biochim Biophys Acta - Mol Cell Biol Lipids Elsevier BV. 2009;1791:254-62. https://doi.org/10.1016/j.bbalip.2009.01.016.

91. Vigerust NF, Cacabelos D, Burri L, Berge K, Wergedahl H, Christensen B, et al. Fish oil and 3-thia fatty acid have additive effects on lipid metabolism but antagonistic effects on oxidative damage when fed to rats for 50 weeks. J Nutr Biochem BioMed Central. 2012;23:1384-93. https://doi.org/10.1016/j. jnutbio.2011.08.006.

92. Varki A, Freeze HH, Gagneux P. Evolution of Glycan Diversity. Essentials Glycobiol. 2009:281-689. NBK1942 [bookaccession]

\section{Ready to submit your research? Choose BMC and benefit from:}

- fast, convenient online submission

- thorough peer review by experienced researchers in your field

- rapid publication on acceptance

- support for research data, including large and complex data types

- gold Open Access which fosters wider collaboration and increased citations

- maximum visibility for your research: over $100 \mathrm{M}$ website views per year

At BMC, research is always in progress.

Learn more biomedcentral.com/submissions 